\title{
Switzerland: Selected Issues
}

This Selected Issues paper for Switzerland was prepared by a staff team of the International Monetary Fund as background documentation for the periodic consultation with the member country. It is based on the information available at the time it was completed on May 9, 2006. The views expressed in this document are those of the staff team and do not necessarily reflect the views of the government of Switzerland or the Executive Board of the IMF.

The policy of publication of staff reports and other documents by the IMF allows for the deletion of market-sensitive information.

To assist the IMF in evaluating the publication policy, reader comments are invited and may be sent by e-mail to publicationpolicy@imf.org.

Copies of this report are available to the public from

International Monetary Fund $\bullet$ Publication Services

700 19th Street, N.W. • Washington, D.C. 20431

Telephone: (202) 6237430 • Telefax: (202) 6237201

E-mail: publications@imf.org • Internet: http://www.imf.org

Price: $\$ 15.00$ a copy

\section{International Monetary Fund Washington, D.C.}





\title{
INTERNATIONAL MONETARY FUND
}

\author{
SWITZERLAND
}

\section{Selected Issues}

Prepared by Alina Carare (EUR), May Khamis (MFD), and Xavier Debrun (FAD)

Approved by the European Department

May 9, 2006

Contents

I. Coordinating Fiscal Policy in Switzerland: Issues, International

Experience and Prospects 4

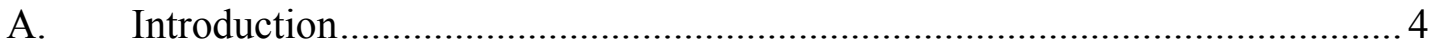

B. The Benefits and Costs of Decentralization ................................................ 5

Fiscal Federalism: Benefits and Limits ................................................... 5

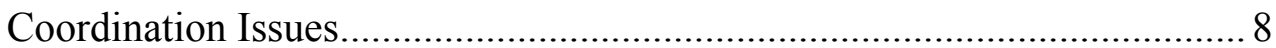

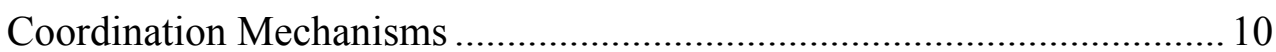

C. Swiss Fiscal Federalism at Work ……………........................................... 13

Fiscal Policy Coordination in Switzerland ................................................ 13

Public Debt and Expenditure: Growing Problems...................................... 16

Assessing Fiscal Behavior(s) .............................................................. 18

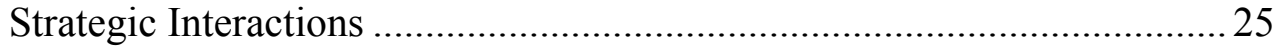

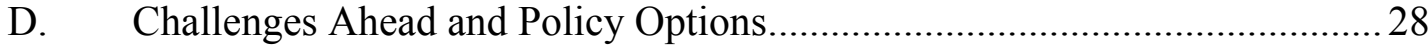

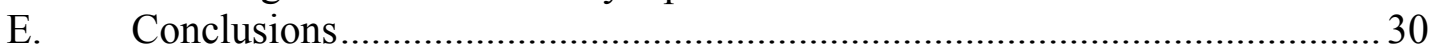

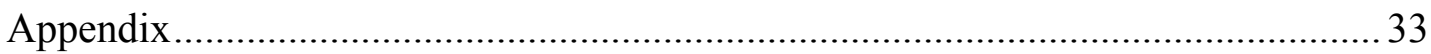

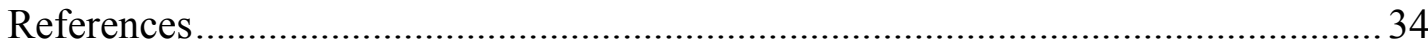

II. An Indicative Public Sector Balance Sheet for Switzerland.......................................37

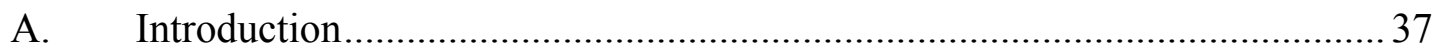

B. Some Preliminary Findings........................................................................... 38

C. The Balance Sheet for the Two Main Levels of Government ........................ 42

D. Conclusions and Policy Relevance .............................................................. 43

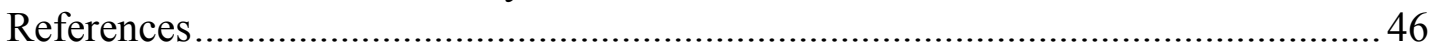

III. A Comparison of the Swiss, Dutch, and U.K. Pension Systems, with Emphasis on the Occupational Pension Pillars........................................................4 47

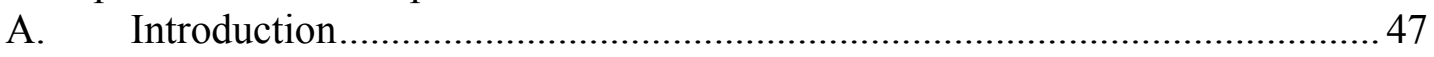

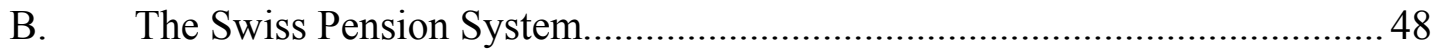




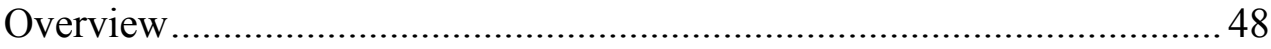

Regulation and Supervision ..................................................................... 49

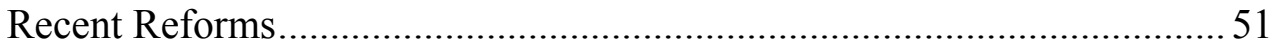

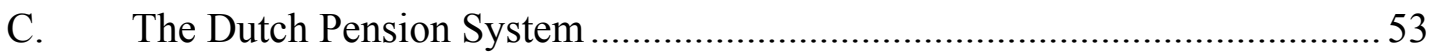

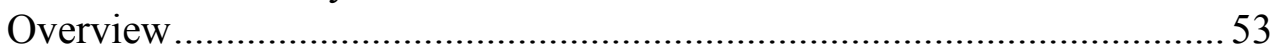

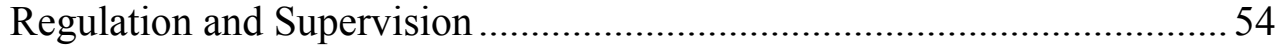

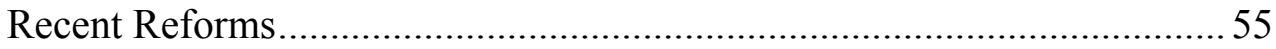

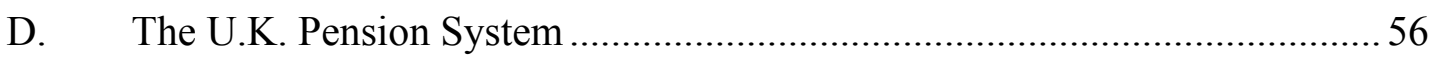

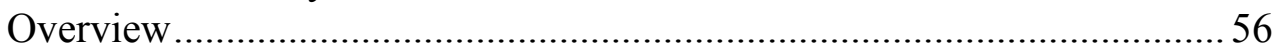

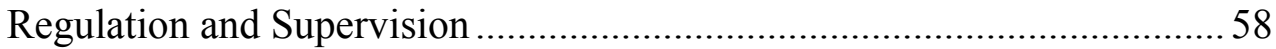

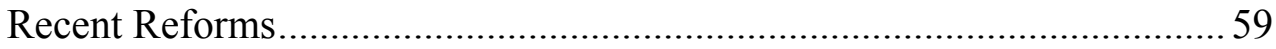

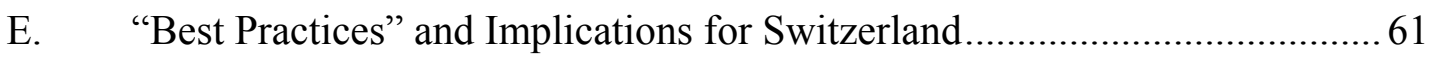

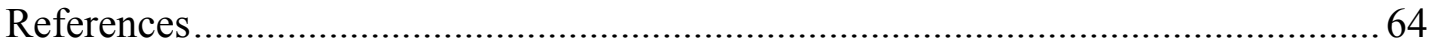

Boxes

III. 1. Switzerland-Amendments to the BVG Law, 2004-06.........................................51

2. The Netherlands-The New Financial Assessment Framework for Pension Funds ......................................................................................56

3. The U.K.- Main Elements of the New Funding Standard for Pensions Funds .... 59

4. The U.K. - Key Proposals of the Pensions Commission.......................................... 61

Figures

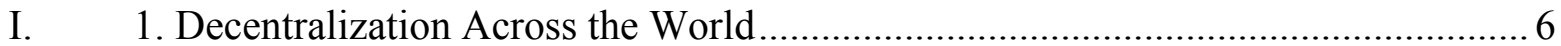

2. Borrowing Restrictions in Selected Countries....................................................... 10

3. Mechanisms of Vertical Coordination in Selected Countries................................. 12

4. General Government Expenditure in Selected European Countries........................ 16

5. Public Debt Developments .............................................................................. 17

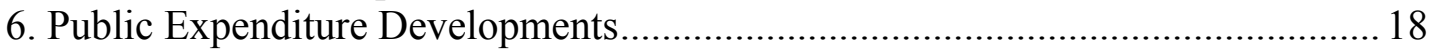

7. Selected Expenditure Indicators for the Confederation.........................................2 27

Tables

I. 1. The Distribution of Tasks between Central and Subcentral

Governments in Selected Countries................................................................

2. Average Fiscal Behavior in a Panel of 18 Industries Countries .............................2 20

3. Fiscal Behavior in Selected Federal Countries ...................................................22

4. Fiscal Behavior by Level of Government............................................................2 23

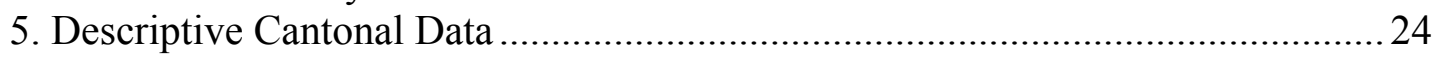

6. Standardized Corporate Income Tax Payments in Selected Countries...................26

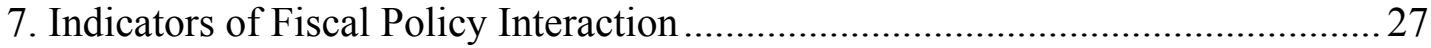

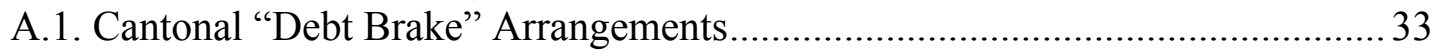

II. 1. General Government Financial Assets and Liabilities ..........................................38

2. General Government Expanded Financial Assets and Liabilities .......................... 40

3. Public Sector Balance Sheet .......................................................................... 41

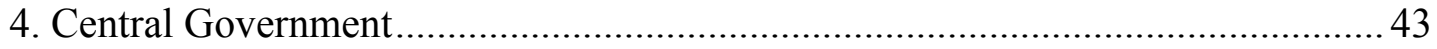




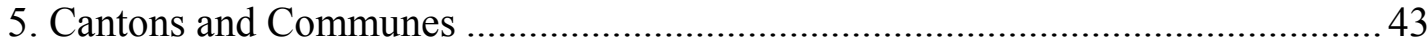

6. Detailed Public Sector Balance Sheet............................................................... 45

III. 1. Corrective Actions by Swiss Pension Funds, 2004 ........................................... 52

2. Corrective Actions by Dutch Pension Funds, 20002-04 …................................55

3. Occupational Pension Systems in Switzerland, The Netherlands, and the U.K.... 63 


\section{CoOrdinating Fiscal Policy in Switzerland: Issues, International EXPERIENCE AND PROSPECTS ${ }^{1}$}

\section{A. Introduction}

1. The redistribution of policy responsibilities from national authorities to other levels of government has attracted considerable attention in recent years. In a number of European Union member states, important prerogatives have been consolidated in supranational bodies or devolved to subnational entities (e.g. Belgium, France, and Italy). Decentralization is keenly debated in traditionally centralized countries, whereas reforms of intergovernmental fiscal relations have been envisaged or implemented in already highly decentralized countries, such as Germany, Spain, and Switzerland. Although the extent of fiscal decentralization typically reflects political considerations rooted in a country's history, geography, and demography, economic incentives also play a central role, suggesting that intergovernmental fiscal relations need to respond to changes in the economic environment.

2. The economic literature traditionally contends that decentralization favors a better match between the supply and the demand for public goods and services. One reason is that citizens' preferences and needs have a regional dimension that local policymakers are better able to observe. Another is that the proximity between policymakers and constituents enhances democratic accountability, and reduces the risk of discrepancy between policymakers' objectives and incentives, and the interests of the community.

3. Yet decentralization also faces limits. First, it is difficult to design a clear-cut assignment of tasks between different decision levels, and costly overlaps often result. Second, coordination problems arise when choices by one jurisdiction affect citizens in another, or undermine the efficiency of national policies as regards macroeconomic stabilization, income redistribution, and long-term fiscal sustainability. Third, fragmentation makes it more difficult to realize economies of scale in the production of certain public goods and services. Fourth, issues of equity come up when subnational entities have different financial capacities.

\section{This paper looks at these trade-offs in Switzerland, focusing on challenges for} fiscal policy coordination, and on possible options to address them. Section B reviews the benefits and costs of highly decentralized governments. Coordination issues receive particular attention. Section $\mathrm{C}$ describes the Swiss institutional architecture, and provides a cross-country analysis of Switzerland's fiscal performance over the last three decades.

\footnotetext{
${ }^{1}$ Prepared by Xavier Debrun (FAD). Part of the cantonal data used in this paper were kindly provided by Professor Lars P. Feld and the University of St Gallen.
} 
Section D discusses the specific policy challenges in the Swiss federalist state related to population aging. Some policy implications are drawn in Section E.

\section{For Switzerland, the analysis points to the following main conclusions:}

A. The diversity of objectives across government levels and a relatively weak intertemporal perspective make it difficult to set an ex-ante fiscal stance for the general government. This may explain the ex post procyclical fiscal policies. Subfederal entities are the main contributors to these tendencies.

B. While competitive fiscal federalism is effective in avoiding a proliferation of new spending programs, it is less ideally equipped to cope with pressures from existing (entitlement) programs, which implies clear fiscal risks in the face of population aging. Coordination among governments is important to avoid delays in implementing credible policy responses, the demise of the fiscal rules, or undue tax increases.

C. The reform of financial equalization and of the distribution of tasks between the Confederation and the Cantons-Neuordnung des Finanzausgleich or $\mathrm{NFA}^{2}$ - is a welcome development. The NFA improves incentives to lower costs at the cantonal level, clarifies the tasks of federal and subfederal governments, and mandates coordination among Cantons in key areas, including education and health.

D. Looking forward, implementing the NFA without delays and alleviating coordination problems between federal and cantonal levels should improve the ex-post fiscal stance and the intertemporal profile of fiscal policy. In that regard, greater transparency on medium-term challenges and policy options at all levels of the general government could foster an ex-post coordinated response. Also, the extension of fiscal rules akin to the federal "debt brake" to more entities could strengthen the fiscal anchor of the general government, discourage free riding, and foster structural fiscal reforms.

\section{B. The Benefits and Costs of Decentralization}

\section{Fiscal Federalism: Benefits and Limits}

6. Devolving policy responsibilities to subnational governments can improve social welfare through a better matching of the demand and supply of public goods. On the demand side, needs and preferences for public goods and services (in quality and quantity) may vary across regions of a given country (or municipalities of a given state), reflecting different socio-economic conditions, economic structures, or geographical features (Oates, 1972). On the supply side, local policymakers have more accurate information, and are therefore better placed to tailor public goods to local conditions. Also, decentralization keeps

\footnotetext{
${ }^{2}$ The NFA was approved by federal referendum in November 2004 and is expected to come into force in 2008.
} 
policymakers close to their constituents, which enhances democratic accountability and reduces possible gaps between the pursuit of the common good and private objectives.

7. Yet decentralization has its limits. First, it is difficult to design a clear-cut assignment of policy responsibilities among different levels of government because most policy areas (e.g. education or hospital care) involve many dimensions (e.g. fixed investment, curriculum, salaries), which may not all be suitable for decentralization. The outcome may be costly overlaps across jurisdictions (e.g. redundant infrastructures), insufficient incentives for cost effectiveness (e.g. ill-designed grant financing), or unfunded mandates. Second, decentralization reduces the scope for economies of scale, which also reduces overall cost-effectiveness of providing public goods and services. Third, costly coordination failures are possible. They are discussed in greater detail below.

8. These limitations are highly country-specific. The extent of decentralization thus varies widely across the world (Figure 1). Switzerland emerges as one of the most decentralized government systems, surpassed only by Canada among industrial countries. The discrepancy between the revenue and expenditure shares of subnational governments (or vertical imbalance) is also smaller than in the world sample (Switzerland is located relatively close to the 45-degree line depicted in the right panel of Figure 1).

Figure 1. Decentralization Across the World (98 countries-average 1972-2000)

Share of subnational governments in general government
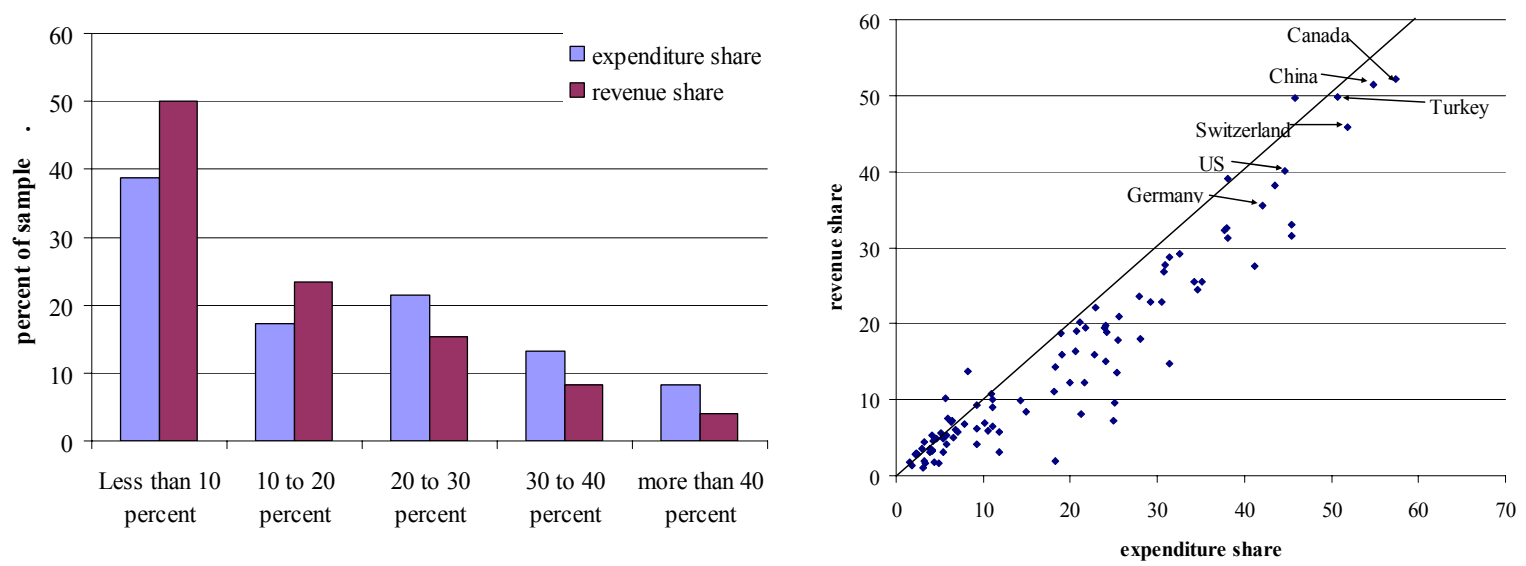

Sources: Government Finance Statistics and IMF staff calculations.

9. Despite significant differences of view on the merits of decentralization, economic theory suggests several widely accepted principles guiding the distribution of responsibilities between central and subcentral governments. Broadly speaking, functions concerning macroeconomic stabilization and redistribution-along with intrinsically "national" public goods such as defense and foreign relations - should be performed by the center, while other, more allocative, functions (such as education, public 
transport, sanitation, etc) are potential candidates for devolution to subnational entities. The reasons for keeping stabilization at the centre includes easier coordination with monetary policy, avoidance of free-riding problems, risk-sharing opportunities (through equalization transfers, and the national tax-transfer system), and "scale economies" (including better borrowing conditions, access to a larger and less mobile tax base, and smaller Ricardian effects $\left.{ }^{3}\right)$. The rationale for centralizing redistributive policies follows from the "adverse selection" problem created by household mobility within national borders (Stigler, 1957), as net contributors move to low-tax-low-transfers areas, and net beneficiaries concentrate in high-tax-high-transfers areas (Wildasin, 1991).

10. The actual distribution of tasks between national and subnational entities for a sample of industrial and developing economies reveals two notable trends (Table 1). First, all functions listed in the table are concurrent in at least one country of the sample, signaling both the high degree of country-specificity in the determinants of intergovernmental fiscal relations and the difficulty to design a clear cut assignment of tasks. Second, predominantly national public goods emerge as functions related to defense, foreign relations and the operation of the national economic union. As the sample does not include Switzerland, shaded entries identify the country's position.

Table 1. The Distribution of Tasks between Central and Subcentral Governments in Selected Countries

\begin{tabular}{|c|c|c|c|}
\hline Functions & National & Subnational & Concurrent \\
\hline Defense & 95.2 & 0.0 & 4.8 \\
\hline Foreign affairs & 85.4 & 0.0 & 14.6 \\
\hline Old age and disability pensions & 82.5 & 0.0 & 17.5 \\
\hline Competition & 80.0 & 5.0 & 15.0 \\
\hline Justice & 80.0 & 0.0 & 20.0 \\
\hline Labor market & 76.2 & 2.4 & 21.4 \\
\hline Higher education & 59.5 & 21.4 & 19.0 \\
\hline Local police & 36.8 & 52.6 & 10.5 \\
\hline Health & 30.0 & 7.5 & 62.5 \\
\hline Social assistance & 29.3 & 22.0 & 48.8 \\
\hline Transport infrastructure & 27.9 & 14.0 & 58.1 \\
\hline Primary and secondary education & 21.4 & 47.6 & 31.0 \\
\hline Sanitation & 12.2 & 63.4 & 24.4 \\
\hline Waters & 9.8 & 56.1 & 34.1 \\
\hline Local transport & 7.1 & 66.7 & 26.2 \\
\hline Garbage collection & 7.3 & 82.9 & 9.8 \\
\hline \multicolumn{4}{|c|}{$\begin{array}{l}\text { Source: OECD/World Bank (2003), and IMF staff calculations. } \\
\text { Note: Sample size varies between } 38 \text { and } 43 \text { countries depending on the task. Numbers show } \\
\text { the percentage of countries where the task in line is performed by the government level in column, } \\
\text { or concurrently (third column). For Switzerland, IMF staff relied on Dafflon (2004) and the }\end{array}$} \\
\hline
\end{tabular}

\footnotetext{
${ }^{3}$ The downsizing of Ricardian effects results from the fact that liabilities created by centralized stabilization efforts are shared by the entire federation. Using Canadian data, Bayoumi and Masson (1998) estimate that stabilization policy is two to three times more effective (in terms of offsetting the shocks on real disposable income) at the federal level than at the provincial level.
} 


\section{Coordination Issues}

11. Coordination issues are either horizontal-between jurisdictions on the same level-or vertical—between different levels of government. Horizontally, decisions implemented in one jurisdiction may affect welfare elsewhere, either through direct externalities (e.g. an international airport), or through location choices of individuals and businesses. Absent ex-ante coordination, decentralization may typically entail an underprovision of goods and policies with positive externalities (e.g. road network, recreation areas, public libraries, and other hardly excludable goods), and an overprovision of goods and policies with negative externalities (e.g. business-friendly zoning and infrastructures, "predatory" tax systems intended to attract certain categories of mobile taxpayers).

\section{Vertically fragmented fiscal policymaking may undermine the efficiency of the} general government budget as a tool of macroeconomic stabilization. In a noncooperative setting, the fiscal stance of the general government is not set ex-ante in line with national objectives, but results from autonomous decisions by each policymaker taking the actions of others as given. As stabilization is typically a second-order consideration for subcentral entities (see above), their policies are more likely to result in procyclical fiscal impulses. ${ }^{4}$ Also, the smaller size of central tax-transfer systems (including financial equalization arrangements) inevitably limits horizontal insurance in the face of regionspecific shocks (see e.g. von Hagen, 1999; and Fatàs, 1998) ${ }^{5}$.

\section{Social and income redistribution policies may suffer with decentralization,} leading to pressure on central government finances to compensate. The adverse selection problem described above may encourage subnational entities to provide suboptimally low levels of redistribution. The central government finds itself in a weak position to refuse supplementary funding for such expenditure programs, known for their political sensitiveness (Sutherland, Price and Joumard, 2005). This point is particularly relevant in the context of population aging, as the costs of many social programs are creeping up whereas the adverse selection problem may be worsening. With limited willingness and/or ability for subnational entities to bear the rising costs of social programs, the central government thus becomes the natural "financier of last resort."

\section{A sensible vertical distribution of tasks can reduce the scope for coordination} problems, but it cannot eliminate them. The main reason is that it is in general impossible to find one-to-one correspondences between policy targets and instruments. Typically, each

\footnotetext{
${ }^{4}$ In particular, when stabilization is not a concern, revenue windfalls are more likely to be spent, and adjustments are most likely to be carried out in bad times.

${ }^{5}$ Studies surveyed by von Hagen (1999) — mainly on the US — suggest that on average, the federal tax-transfer system offsets only 10 to 15 percent of regional shocks on state disposable income (with a range of 7 to 40 percent). Fatàs (1998) argues that those studies overestimate the true insurance component "by a factor 3" as one needs to correct for the intertemporal smoothing provided by automatic stabilizers in each state.
} 
instrument - i. e., a tax measure or a spending program - affects multiple policy targetsgrowth, employment, macroeconomic stability, income redistribution - on which each government level places a different emphasis. In such a setting, no clever assignment of tasks can ensure the best possible performance on all objectives, and policy coordination is needed to establish priorities. Coordination problems are most obvious with respect to macroeconomic stabilization (traditionally a national objective). For example, subnational governments may find it individually optimal to launch valuable investment projects when financing conditions are favorable. Yet this could add unwanted macroeconomic stimuli to a booming economy.

\section{Decentralized fiscal policymaking may be less conducive to fiscal discipline, prompting many countries to impose restrictions on subnational borrowing (Figure 2). ${ }^{6}$}

First, the possibility of a bailout by the center may weaken the perception of hard budget constraints at the subnational level. A related issue is the incentive for subnational governments to outsource fiscal stabilization to the center by demanding additional transfers. As already noted, outsourcing is more appealing, the greater the role of subnational government in politically sensitive programs. Second, subnational governments are individually less exposed to the unpleasant financial repercussions of excessive public debt accumulation such as higher expected inflation and interest rates (Beetsma and Bovenberg, 1999). Third, intergovernmental financial arrangements themselves may carry the seeds of fiscal indiscipline. Specifically, high dependency of subnational finances on intergovernmental transfers implies that policymakers fail to fully internalize the economic costs of public spending through taxation. Fourth, fiscal retrenchments are likely to be more difficult to implement in decentralized fiscal systems because decentralization adds a layer of complexity to the "war of attrition" over sharing the burden of adjustment. Finally, decentralization may reduce the transparency and timelines of fiscal accounts, potentially reducing the benefits of closer democratic control ${ }^{8}$ and the disciplining effect of financial markets. ${ }^{9}$

\footnotetext{
${ }^{6}$ For a recent and comprehensive survey of fiscal rules at the subcentral government level, see Sutherland, Price, and Joumard (2005).

${ }^{7}$ Alesina and Drazen (1991) show how a "war of attrition" between two groups of equal size that disagree on sharing the costs of a fiscal adjustment delays fiscal stabilization until the expected costs of fiscal indiscipline become too high for one group.

${ }^{8}$ Democratic accountability reduces potential discrepancies between policymakers objectives and social welfare, and thereby, the relevance of politically motivated deficit bias.

${ }^{9}$ The disciplining role of financial markets in federations is generally thought to be quite weak. In the case of Switzerland, Küttel and Kugler (2001) indeed find that fiscal indicators such as debt and the budget balance do not affect cantonal yield spreads. In contrast, institutional factors (e.g. the extent of mandatory referendums on new expenditure programs) and geographical features (e.g. Cantons with large cities) appear to matter.
} 
Figure 2. Borrowing Restrictions in Selected Countries (relative frequency in the sample)

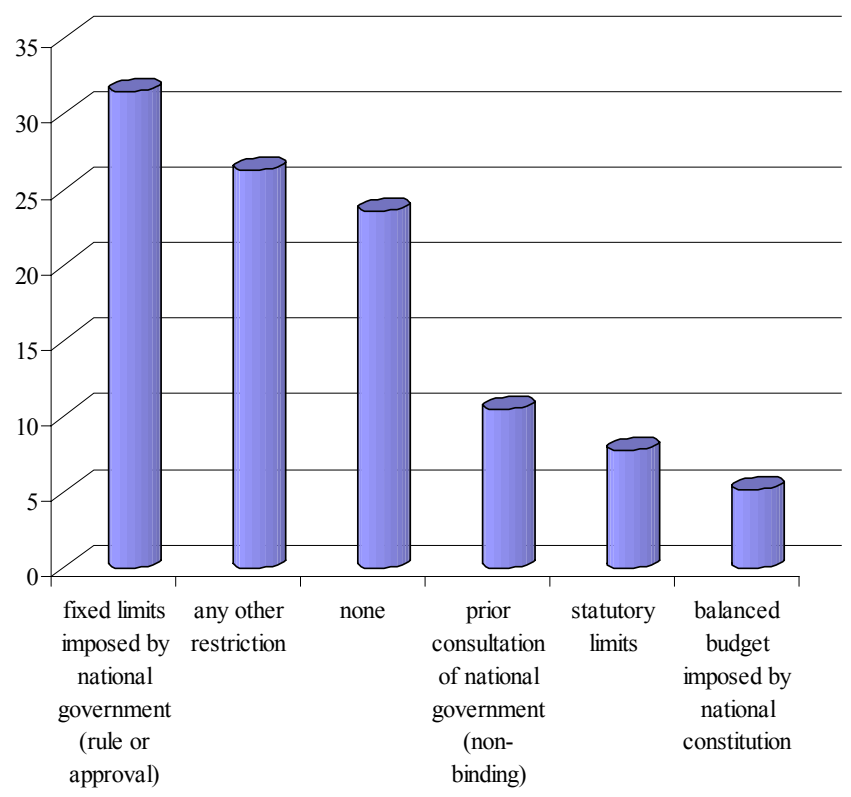

Source: OECD/World Bank (2003).

\section{Coordination Mechanisms}

16. Policy coordination can take many forms, involving varying degrees of constraint on policymakers' discretion. At the "soft" end of the spectrum, the open method of coordination (or OMC) operates through benchmarks characterizing best practices. An open exchange of information on policies provides implicit rewards and punishments - including through peer pressure - which ultimately affect policies. In its stronger form, the OMC may involve explicit "scoring" or "naming and shaming" practices. The OMC is useful in cases where institutionalized (i.e. ex-ante) forms of coordination are politically difficult to put in place, and where binding commitments are not necessary to improve outcomes - that is essentially when policy competition is expected to lead to a cooperative equilibrium. ${ }^{10}$

\footnotetext{
${ }^{10}$ That argument helps explain why structural policy coordination in the EU is based on the OMC - the socalled Lisbon strategy. On the one hand, ex-ante coordination is difficult because of the Member States' reluctance to see "Brussels" impinge on sensitive matters like labor market policies. On the other hand, the competitive dimension of liberalization measures makes ex-ante commitments less necessary as a way to foster mutually beneficial structural reforms.
} 


\section{In decentralized fiscal systems, relatively strong ex-ante coordination mechanisms are often in place.}

E. Horizontally, subnational entities sometimes join forces through special purpose entities (e.g. water distribution or school districts), binding cooperation agreements, and sometimes, outright amalgamation. ${ }^{11}$ These forms of coordination work best when incentives for cooperation are high, say to exploit economies of scale. Horizontal coordination on the provision of public goods carrying significant externalities can also be envisaged to the extent that both parties clearly perceive the higher costs of a noncooperative interaction. In contrast, harmful tax competition is unlikely to be credibly resolved through such mechanisms. ${ }^{12}$

F. Vertically, the idea is either to limit discretion at the subnational level by promoting national spending priorities (e.g. through conditional grants) and constraining tax parameters (e.g. through tax sharing or harmonization), or to encourage in various ways subnational governments to adopt budgets consistent with national macroeconomic objectives. In principle, medium-term financial plans covering all levels of government provide a useful framework for vertical coordination. This, however, requires extensive ex-ante negotiation at all stages of the budget process - from preparation to implementation - akin to centralized policymaking, and is therefore likely to be difficult in decentralized countries. In practice, vertical coordination often involves targeting rules imposed by (or negotiated with) the center (see Figure 3), and in some cases contractual agreements (such as the Accords de Coopération in Belgium). However, implicit policy coordination can be promoted through the adoption of uniform budget procedures, identical macroeconomic assumptions, and full disclosure of relevant information (see Figure 3).

\footnotetext{
${ }^{11}$ Municipal mergers are not uncommon. In 1975, Belgium undertook a one-off merger operation, reducing the number of communes from 2498 to 589. In Switzerland, the process is ongoing; there were 3021 communes in 1990; 2899 in 2000; and 2763 on January 1, 2005.

${ }^{12}$ Tax competition is harmful if it prevents government to raise sufficient tax revenues to finance the public goods and services demanded by the population.
} 


\section{Figure 3. Mechanisms of Vertical Coordination in Selected Countries ${ }^{13}$}

(relative frequency in the sample)

Role of the center in subnational spending decisions

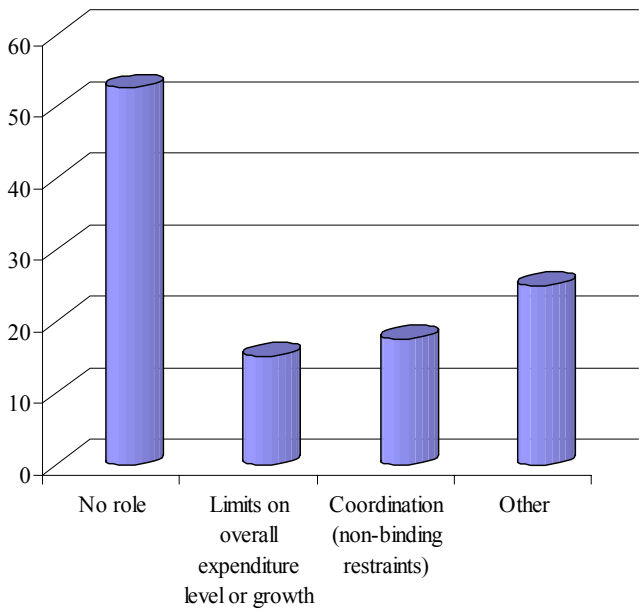

Budgeting standards

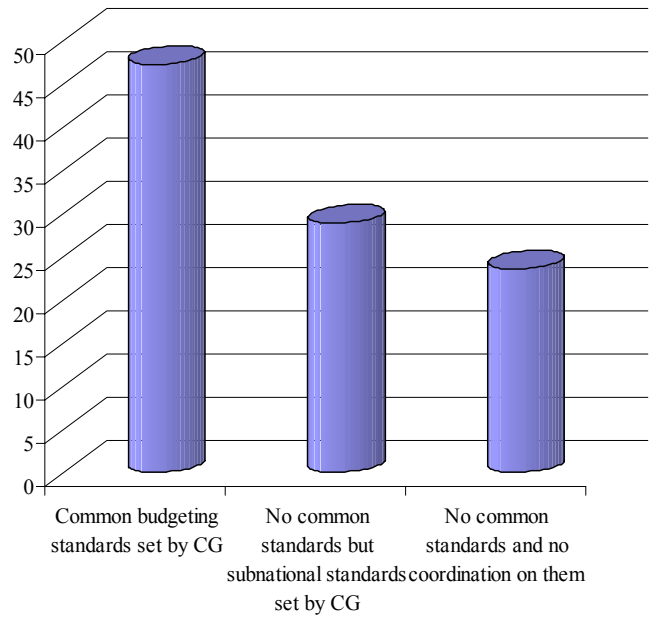

Targeting systems in countries where the center plays a role

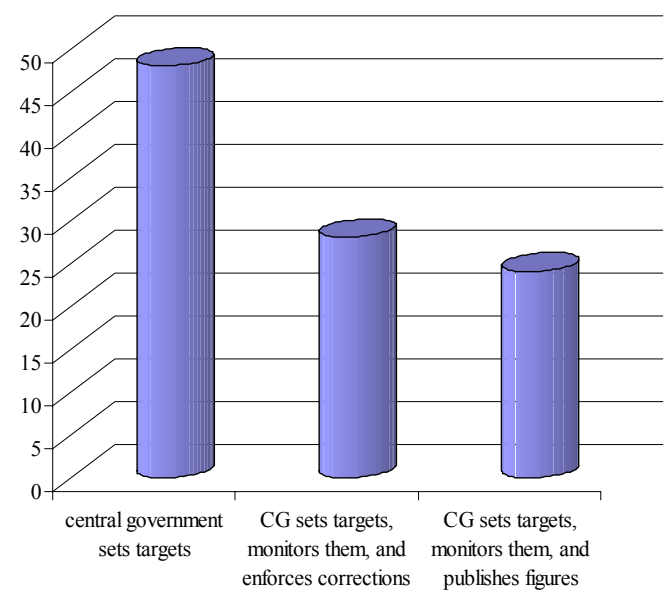

Information sharing

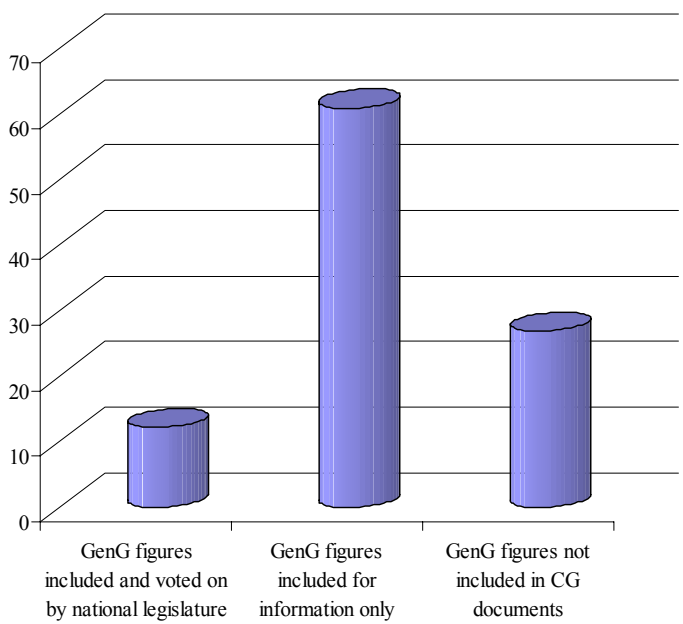

Source: OECD/World Bank (2003).

${ }^{13}$ In Switzerland (not included in the OECD/World Bank sample), the NFA moves away from conditional grants towards unconditional ones. Cantons have no medium-term budgetary frameworks, and the Confederation has no power to impose any coordination rule (see below). Finally, accounting standards between the Confederation and the Cantons are not the same. 


\section{Swiss Fiscal Federalism at Work}

18. This section gathers empirical evidence on Swiss fiscal policy over the last 3 decades. As macroeconomic coordination issues discussed above receive particular attention, the first subsection presents the institutional framework for coordination in Switzerland. The second subsection provides key stylized facts, while the third one ties these to an analysis of the determinants of fiscal policy in a cross-country setting. The fourth subsection discusses evidence of strategic interactions among fiscal policymakers.

\section{Fiscal Policy Coordination in Switzerland}

19. Swiss competitive fiscal federalism gives ample room for policy discretion at the subnational level. In Tiebout's (1956, p. 418) words, "the consumer-voter may be viewed as picking that community which best satisfies his preference pattern for public goods." In that model, policymakers have strong incentives to provide high-quality services at a minimum cost. Direct democracy also fosters citizens' effective power to vote not just with their feet (as assumed in Tiebout's quote) but also with their voice. The importance of horizontal competition inevitably limits the use of formal, ex-ante coordination mechanisms, especially those involving the center.

20. While the Federal Constitution grants considerable autonomy to the Cantons, ${ }^{14}$ it does not preclude extensive horizontal and vertical coordination. The general principle that the Confederation must "respect the autonomy of Cantons" (Article 47) effectively prevents a top-down approach to vertical coordination. However, the Constitution invites policymakers at all levels to cooperate (Article 44), which implies in particular that the Cantons may participate in federal decisions (Article 45.1), and that they must enforce federal laws (Article 46.1). The Constitution also prohibits unfunded mandates arising from federal law, and demands that a "fair" financial equalization mechanism be organized (Article 46.3). The Confederation is required to provide detailed information on policy initiatives to Cantons, and, when their interests are at stake, to consult with them (Article 45.2). Horizontally, the Constitution establishes a legal instrument supporting cooperation agreements among Cantons: the intercantonal conventions (Article 48). The Confederation can, within the limits of federal prerogatives, take part in such conventions.

21. The Federal Constitution imposes some tax policy coordination. Vertical coordination is achieved through a clear allocation of tax instruments to each level of government, ${ }^{15}$ and numerical caps on federal tax rates (Articles 128 and 130). ${ }^{16}$ Horizontally,

\footnotetext{
${ }^{14}$ Article 3 of the Constitution states that the Cantons are sovereign and exert all prerogatives not explicitly delegated to the Confederation. The limits of municipal autonomy and forms of coordination at the municipal level are a cantonal matter (Article 50) and will not be discussed in detail here.

${ }^{15}$ Each government level has access to two sources of taxation, namely direct taxation (for all levels), and another, level-specific source (indirect taxation for the Confederation, tax sharing arrangement for the Cantons, and user charges for the municipalities). See Dafflon (2000) for further analysis.
} 
the Confederation can enact laws prohibiting "unjustified" tax holidays, and harmonizing tax bases, collection principles, and legal procedures (Article 129). In contrast, rates, brackets and (within limits) exemptions are not subject to harmonization, leaving the door open to tax competition among Cantons.

\section{The Federal Constitution is largely non-binding regarding vertical coordination} on macroeconomic objectives. Specifically, Article 100.1 mandates the Confederation to ensure macroeconomic stability (smooth the business cycle and maintain price stability), whereas Cantons and Communes are only required to take into account the business cycle when setting their own fiscal policy (Article 100.4).

23. Other formal coordination mechanisms, however, are at work. They include specialized Cantonal Conferences. Among them, the Conference of Cantonal Finance Directors organizes horizontal coordination on financial matters to be discussed with the federal government, and circulates information on financial issues. Still the Conference does not operate as a forum of negotiation leading to genuine ex-ante coordination on cantonal policies. The jurisprudence of the Federal Court-Switzerland's supreme judiciary authority-has emerged as an implicit mechanism of policy coordination, especially in tax policy matters (Dafflon, 2000).

\section{The recognition of inefficiencies related to the lack of coordination was one} important motivation behind the NFA. Key dimensions of the reform are to minimize the scope for coordination failures - by streamlining the distribution of tasks between Cantons and the Confederation — and to improve vertical and horizontal coordination.

\section{The NFA significantly enhances horizontal coordination by defining 9 areas in} which intercantonal conventions are mandatory, including hospitals, higher education, culture, and local transport. The rationale for making coordination compulsory in these matters is to eliminate free-riding behaviors and thereby make sure that all beneficiaries of a certain public good or service contribute to the costs of providing it (Dafflon, 2004). ${ }^{17}$ To prevent that outsiders undermine the benefits of intercantonal cooperation, it is envisaged that the Confederation could, at the request of a qualified majority of Cantons (18, and in

\footnotetext{
${ }^{16}$ Vertical tax competition arises when two government levels tax the same base (Keen, 1998). As a higher tax rate by say a subnational jurisdiction reduces the base (through supply-side effects), and thereby revenues of the center, the latter has an incentive to increase the tax rate as well, leading to excessive taxation in (the Nash) equilibrium. The constitutional caps on federal tax rates can be viewed as a commitment mechanism preventing such vertical competition. In game-theoretic terms, those caps make the Confederation a Stackelberg leader in the tax setting game, leaving Cantons with full discretion to set their own tax policy. It is, however, less straightforward to rationalize the cap on VAT - an exclusive tax of the Confederation - along those lines. It is important to note that horizontal tax externalities (which may lead to excessively low taxes) dominate vertical externalities if the tax base's sensitivity to the state-level tax is not too high (Keen and Kotsogiannis, 2002).

${ }^{17}$ This implicitly suggests that the threat of imposing user charges was not credible enough-for political or feasibility reasons - to encourage and sustain 'spontaneous' coordination through reputational mechanisms.
} 
some cases 21 ), automatically extend to all Cantons certain conventions deemed of national interest.

\section{Financial equalization mechanisms implicitly discourage "predatory"}

(horizontal) tax competition. Currently, statutory tax rates enter negatively in the formula determining Cantonal indices of "financial capacity" (i.e. the lower the tax rates, the lower net equalization transfers). The NFA preserves a negative link between financial capacity and tax rates by linking the latter to the size of a harmonized tax base. Hence, aggressive reductions in tax rates driven by the desire to attract mobile taxpayers will continue to entail a reduction in net equalization transfers. In contrast, the new equalization system will be neutral on tax reductions affecting immobile tax bases - in essence, not driven by tax competition.

27. The scope for strong forms of vertical coordination remains limited. On the one hand, the NFA addresses some pressing coordination issues, whereas the federal Constitution does not provide necessary authority to the Confederation to impose such coordination. On the other hand, the large and heterogeneous group of Cantons is unlikely to welcome "contractual" forms of vertical cooperation. ${ }^{18}$

\section{Perhaps one underestimated dimension of Swiss fiscal federalism is the implicit} role of the open method of coordination. The $\mathrm{OMC}$ is arguably a natural feature of the Swiss system where each Canton (or even Commune) is seen as a "laboratory" for policy experiments and innovations "without widespread risks of failure" (Dafflon, 2000, Page 3). The introduction of statutory fiscal rules reminiscent of the federal "debt brake" in various Cantons ${ }^{19}$ could be interpreted as one 'spontaneous' manifestation of the OMC. Each government indeed has a chance to learn from the success (or failure) of others (including the federal level), encouraging a certain convergence of policies and institutions towards a freely accepted best practice (ex-post coordination). At the same time, the OMC avoids the strictures of a 'one-size-fits-all' solution, allowing for local variants of the model, and even for the possibility that certain entities do not adopt the model if it does not fit their needs or preferences.

\footnotetext{
${ }^{18}$ In Belgium for example, vertical Cooperation Agreements essentially involve 4 players (the federal government and federated entities). For a description of the Belgian system, see Van Rompuy (2005). Belgium also has an ad-hoc 'concertation committee' between federal and subfederal governments to pre-empt potential conflicts of interest. That said, some intercantonal conventions-e.g., on university financing - involve all Cantons, suggesting that there is scope for broad-based coordination through contractual instruments also in Switzerland.

${ }^{19}$ Schaltegger and Frey (2004) describe statutory "debt brakes" at work or under discussion in a number of Cantons. See also Appendix Table A.1. Feld and Kirchgässner (2005) provide empirical evidence supporting the effectiveness on these rules.
} 


\section{Public Debt and Expenditure: Growing Problems}

29. In comparison to other European countries, general government expenditure in Switzerland is low (Figure 4). Only the Baltic states, Ireland, and Spain (albeit only marginally) spend less relative to GDP. That outcome is generally attributed to the expenditure-containment role of direct democracy within a highly competitive federalism, where the tax base (firms and citizens) appears to be fairly mobile and responsive to tax policy changes. ${ }^{20}$ The Swiss system thus seems to effectively tie the size of government to citizens' demand for public goods and services rather than to the policymakers' willingness to spend, which can be a source of expenditure and deficit bias.

Figure 4. General Government Expenditure in Selected European Countries (2004, percent of GDP)

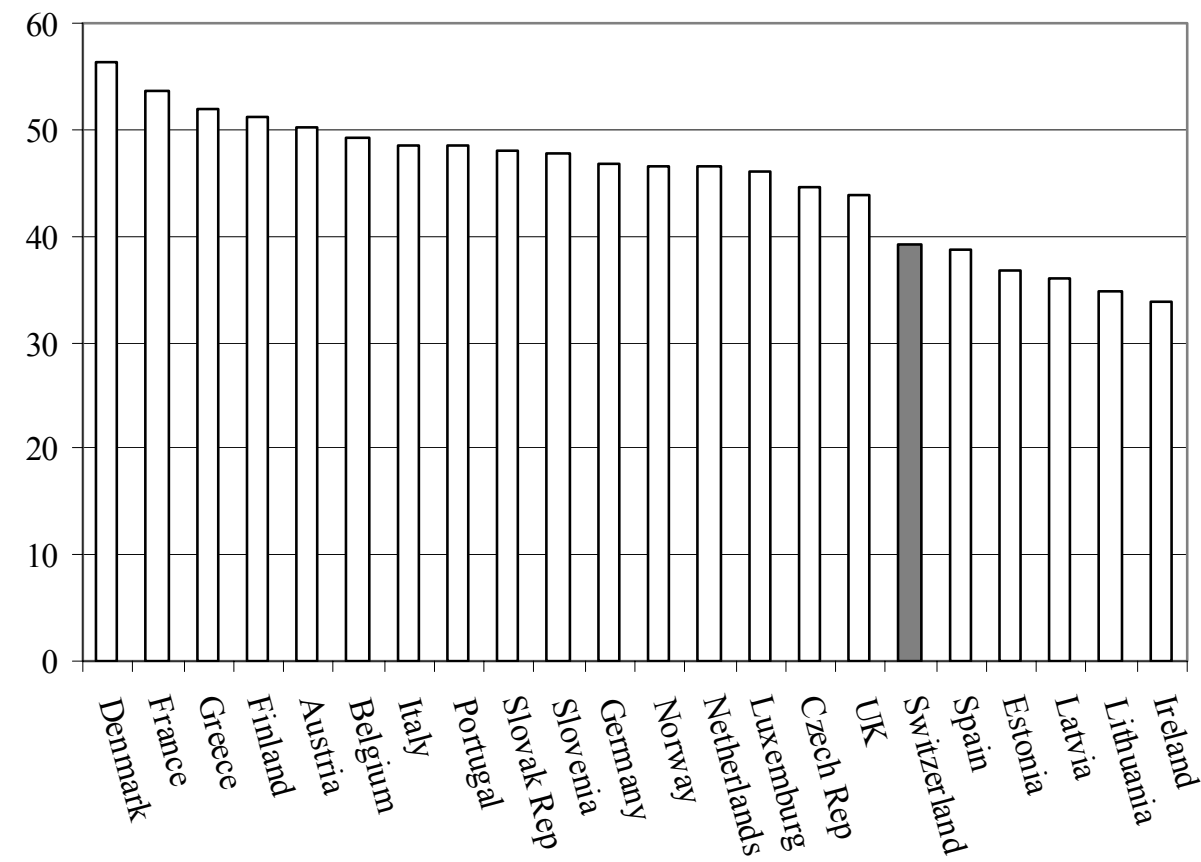

Sources: Eurostat, and IMF.

30. However, since the early 1990s, a protracted period of slow growth combined with increasing pressures on social spending have altered fiscal performance (Figure 5). The public debt-to-GDP ratio, which had been broadly stable over the 1970s and the 1980s, grew rapidly in the 1990s as the primary balance failed to offset the automatic debt accumulation stemming from interest payments (the "snowball effect"). The federal government was by far the largest contributor to the debt increase, owing to sustained

\footnotetext{
${ }^{20}$ See among others Feld and Reulier (2005), Feld, Kirchgässner and Schaltegger (2003), Giorno and Joumard (2002), Feld and Kirchgässner (2002), Kirchgässner and Pommerehne (1996).
} 
primary deficits and to significant off-budget operations, including the recapitalization of public enterprises and support to their pension funds, and the financing of large-scale railway investment projects through a special fund. ${ }^{21}$ The growing importance of off-budget operations during the 1990s is particularly evident from the declining correlation between the overall balance and variations in the public debt.

Figure 5. Switzerland: Public Debt Developments (1970-2004)

Public Debt

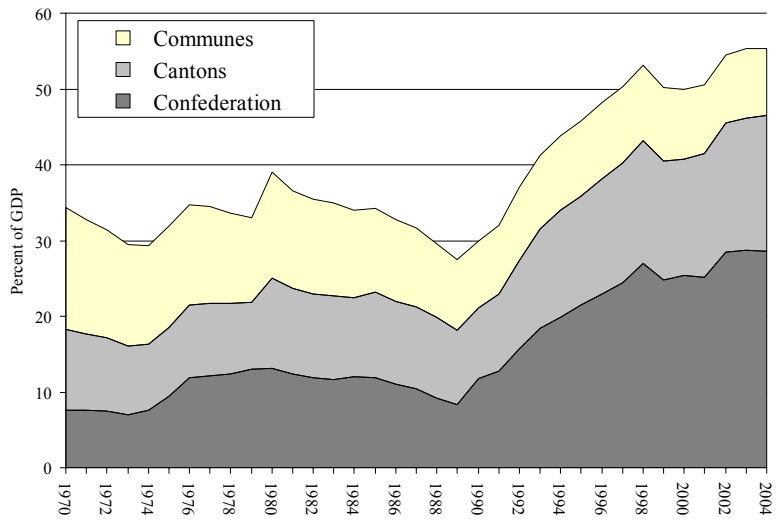

Adverse dynamics (1990-2004)

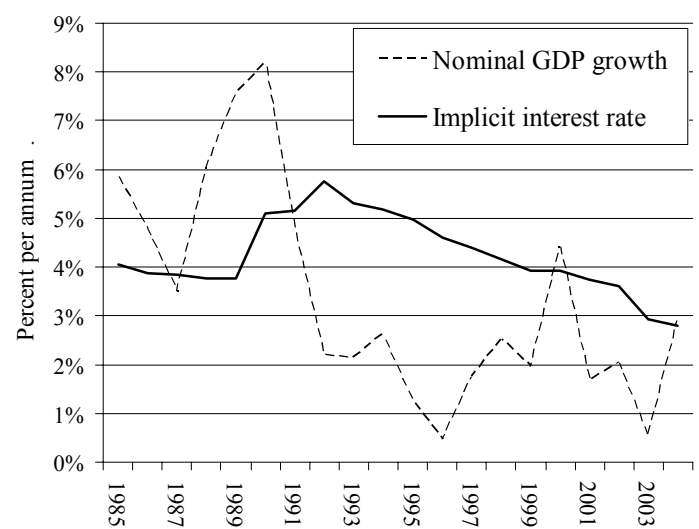

Sources of public debt accumulation (1990-2004)

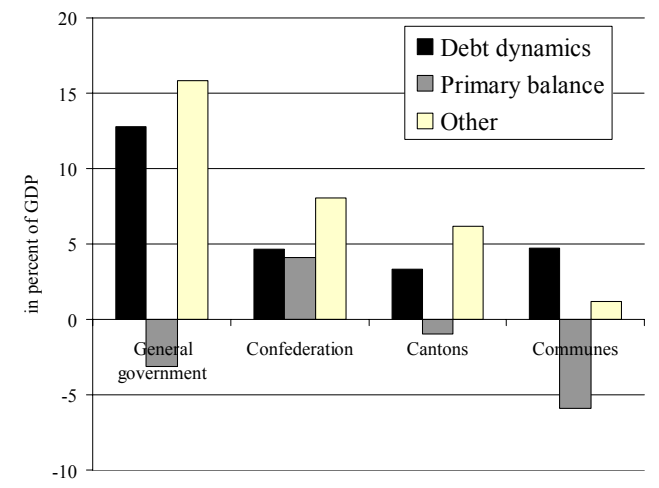

Public debt and the budget balance: weaker link ${ }^{22}$

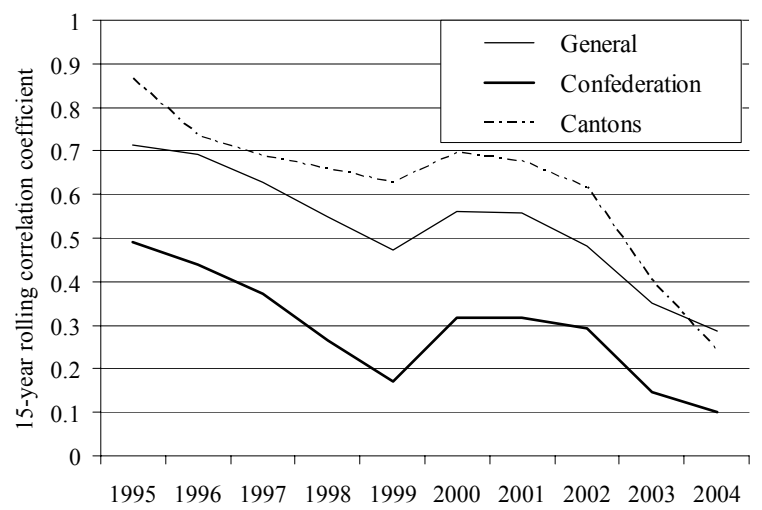

Sources: IMF country desk data, and staff estimates.

\section{Aside from off-budget operations, structural expenditure pressures largely} account for the deterioration of the fiscal situation. On the one hand, the rise in unemployment led to higher social spending - notably through the federal unemployment insurance - with a lagged impact on cantonal social assistance programs, as unemployment

\footnotetext{
${ }^{21}$ Proceeds from the Swiss National Bank gold sales could in part reverse these adverse debt developments.

${ }^{22}$ This panel depicts 15 -year rolling correlation coefficients between the overall balance (in percent of GDP) and the first-differenced public debt relative to current year GDP.
} 
benefits are limited in time. On the other hand, rising real healthcare costs (see IMF, 2004) were reflected in higher current transfers from federal and cantonal governments-mainly health-insurance assistance to low-income households, and transfers to social security programs. Low incentives to enhance cost-effectiveness in existing expenditure programsparticularly those financed with intergovernmental transfers - further contributed to the lack of expenditure restraint (Giorno and Joumard, 2002). Overall, the current primary expenditure of the general government increased by almost 8 percentage points of GDP between 1990 and 2004 (Figure 6).

Figure 6. Switzerland: Public Expenditure Developments (1990-2004) (Current primary expenditure in percent of $G D P^{23}$ )

General government (1990-2004)

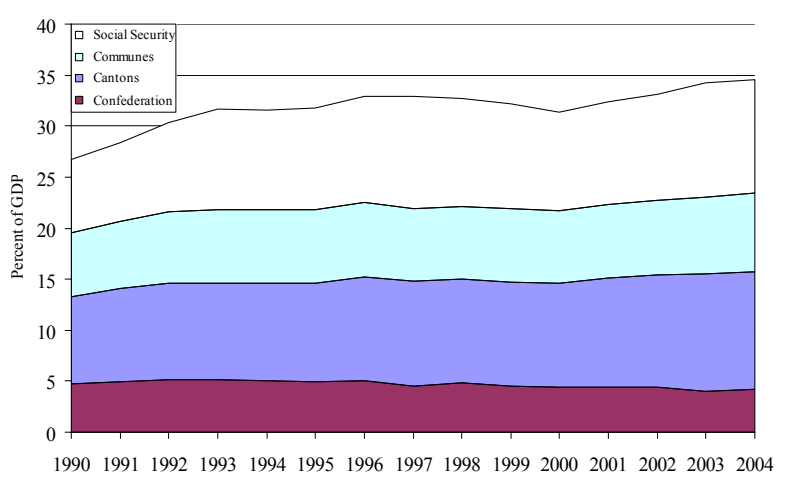

Cumulative increase (1990-2004)

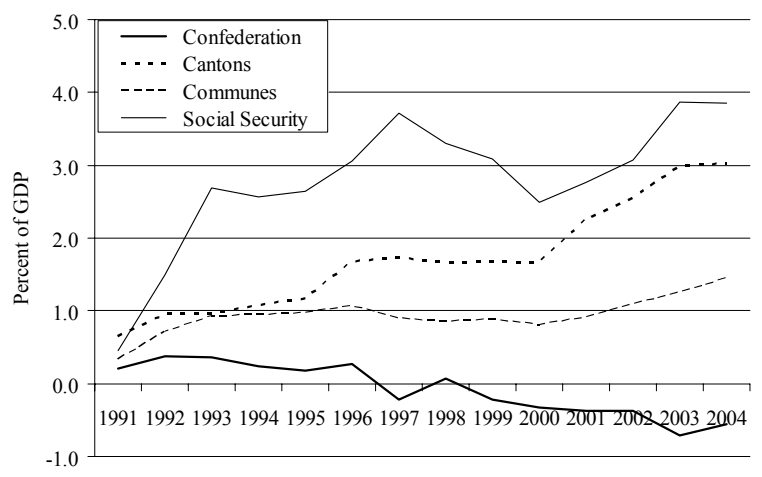

Sources: IMF country desk data and staff estimates.

\section{Assessing Fiscal Behavior(s)}

32. To better grasp the macroeconomic determinants of Swiss fiscal performance, it is useful to place it in cross-country perspective, using a common methodology. To do so, econometric analysis allows checking whether a stable relationship exists between the fiscal stance and some of its key macroeconomic determinants-i.e. cyclical conditions and the concern for long-term solvency. It should be made clear upfront that the estimated model merely describes ex-post, average policy patterns for the period under review, and should not be interpreted as characterizing a systematic ex-ante "reaction function" of the policymakers. Given the relatively short time series available for fiscal policy in most countries (30 to 40 years at best), the literature generally relies on a parsimonious specification ${ }^{24}$ described by equation (1).

\footnotetext{
${ }^{23}$ Intergovernmental transfers are netted out.

${ }^{24}$ Bohn (1998) relates that specification to the "tax smoothing” theory of fiscal policy (Barro, 1979).
} 


$$
p_{t}=\alpha+\lambda p_{t-1}+\beta g a p_{t}+\gamma d e b t_{t-1}+\varepsilon_{t}
$$

using a subscript $t$ to designate year $t$, and where $p$ captures the primary balance (in percent of GDP), gap , the output gap, and debt is the public debt-to-GDP ratio. ${ }^{25}$ The lagged dependent variable is introduced to account for likely persistence in the policymaking process so that $\lambda$ is expected to be positive. Also, the estimated model allows for $\beta$ to differ between good times (positive output gap) and bad times (negative output gap). ${ }^{26}$ A positive sign for $\beta$ means that when GDP growth exceeds potential (i.e. the output gap variable increases), the primary balance improves, in line with a countercyclical response of fiscal policy. In the absence of discretionary fiscal measures, automatic stabilizers should lead to a positive $\beta$. In contrast, a negative $\beta$ would point to a systematic tendency of discretionary fiscal measures to offset automatic stabilizers, signaling a procyclical bias in policymaking. The sign of $\gamma$ is expected to be positive as governments concerned with long-term sustainability tend to increase the primary balance in response to a rise in the public debt ratio (Bohn, 1998).

33. The analysis proceeds in two steps. First, an average fiscal behavior is estimated on a panel including all EU countries (except Luxembourg) as well as Australia, Canada, Switzerland, and the United States. Second, individual country estimates for all federal countries in the sample are compared. ${ }^{27}$

\footnotetext{
${ }^{25}$ Bohn (1998) provides the first systematic discussion of such model, with an application to the US. Galì and Perroti (2003) use panel data techniques to detect the impact of the Maastricht Treaty on policy behaviors in the European Union, while Celasun, Debrun, and Ostry (2006) further refine the panel approach in the context of emerging market economies, and discuss in detail the econometric issues involved. Data used here are from the OECD's Analytical Database and IMF country desk.

${ }^{26}$ See Debrun and Faruqee (2004) and Balassone and Francese (2004).

${ }^{27}$ The null hypothesis of nonstationarity was rejected for all variables except the public debt in Germany and Switzerland. This means that the regression results are not driven by common trends in dependent and independent variables.
} 
Table 2. Average Fiscal Behavior in a Panel

of 18 Industrial Countries (1970-2004)

(dependent variable: primary balance in percent of GDP)

\begin{tabular}{lccc}
\hline & LSDV 1/ & & IV-FE 2/ \\
\hline Primary balance (-1) & $0.72^{* * * *}$ & & $0.73^{* * *}$ \\
Output gap (+) & $0.13^{* * *}$ & & $-0.09^{* *}$ \\
Output gap (-) & $0.25^{* * *}$ & & $0.34^{* * *}$ \\
Public debt (-1) & $0.03^{* * *}$ & & $0.03^{* * *}$ \\
F-test 3/ & & & \\
Federalism & 0.34 & & 0.42 \\
\hline R-squared & 0.78 & & 0.78 \\
Number of obs. & 541 & & 517 \\
\hline
\end{tabular}

1/ Panel least squares with country fixed effects (not reported).

2/ Panel IV estimates, instrumenting the output gap with all other explanatory variables, one lag of these, and two lags of the output gap variables. Country fixed effects are included.

3/ Test of whether federalism leaves the coefficient estimates unaffected. The test is perfomed on a variant that does not dis-tinguish between positive and negative output gaps.

Note: The $*,{ }^{* *}$, and ${ }^{* * *}$ superscripts designate statistical levels of significance of at least 10,5 and 1 percent respectively

34. The industrial countries gathered in this panel tend to run countercyclical fiscal policies in bad times, and exhibit a robust stabilizing response to the public debt. As fiscal policy affects the state of the economy, least-squares estimates of the $\beta$ coefficients may be biased. The second column of Table 2 controls for that reverse causality, using instrumental variables techniques. It appears that the estimated coefficient is positive and significant only in bad times. In good times, the coefficient is negative and non-significant, indicating that automatic stabilizers are offset by procyclical discretionary fiscal impulses. Procyclicality in good times reflects the inherent difficulty for policymakers to resist expansionary pressures when revenues are strong. The positive and significant sign found for $\gamma$ suggests that the intertemporal budget constraint is properly internalized. All other things being equal, a rising debt ratio triggers a fiscal retrenchment and vice versa.

\section{A second salient result is that, as a group, countries with a federal structure do} not appear to behave differently on average than the rest of the sample. ${ }^{28}$ Table 2 reports tests of joint significance of interaction terms between explanatory variables and a dummy identifying federal countries (not displayed). The low values for the corresponding F-tests indicate that the null hypothesis of no effect of federalism cannot be rejected. In fact, country-specific estimates illustrate that federalism, irrespective of its cooperative - as in Austria, Belgium, and Germany — or competitive — as in Canada and the US — nature, does not mechanically entail macroeconomic coordination failures that result in procyclical fiscal

\footnotetext{
${ }^{28}$ Federal countries in the sample include Austria, Belgium (federalism introduced in 1989), Canada, Germany Switzerland, and the United States. Australia could not be analyzed separately due to insufficient data.
} 
policies and neglect for the intertemporal budget constraint (Table 3). ${ }^{29}$ On the one hand, procyclicality and short-term bias in policymaking may stem from constitutional features and political economy factors unrelated to federalism per se (Persson and Tabellini, 2004). On the other hand, as discussed before, coordination issues need not be overwhelming and can be addressed through various institutional mechanisms.

\section{The ex-post fiscal stance in Switzerland appears highly procyclical, and} disconnected from long-run solvency concerns. Unlike the two other countries with competitive federal arrangements, the Swiss fiscal stance on average does not contribute to output stabilization. It appears procyclical in good times, pointing to weak expenditure restraint (or resistance to tax cuts) in the face of temporary revenue gains. In bad times, the fiscal stance is acyclical, indicating a tendency to undertake discretionary adjustment efforts when the economy underperforms. That tendency is strong enough to offset automatic stabilizers. It is important to note, however, that the recent introduction of an annual taxation regime (in 2003) has enhanced the countercyclical role of tax revenues. Also, the fiscal rules adopted by the Confederation (debt brake) and a number of Cantons appropriately encourage a countercyclical fiscal stance. The likelihood of procyclical retrenchments and expansions should therefore be reduced in the future.

\section{The Swiss primary balance does not appear to systematically respond to public} debt developments. Such behavior does not exclude explosive debt paths, and may thus be inconsistent with a proper internalization of the intertemporal budget constraint. Although similar features emerge from German data, they appear more pronounced in the Swiss case. That said, the one-off nature of some large shocks on the Confederation's debt in the 1990s combined with a low initial debt level might have limited the perceived need to aggressively revert such developments with higher primary surpluses, especially in a protracted slow growth episode. This might explain the instability observed in the estimated relationship over the 1990s (see below).

\footnotetext{
${ }^{29}$ Table 3 also reports estimates without distinguishing between good and bad times given the few degrees of freedom and the lower precision of the estimates.
} 
Table 3. Fiscal Behavior in Selected Federal Countries (General Government, 1970-2004) (dependent variable: primary balance in percent of GDP)

\begin{tabular}{|c|c|c|c|c|c|c|}
\hline & Austria & Belgium & Canada & Germany & US & Switzerland \\
\hline Constant & $-1.44 * * *$ & $-2.63 * * *$ & $-4.52 * * *$ & -0.91 & $-2.16 * *$ & -0.42 \\
\hline Primary balance $(-1)$ & $0.50 * * *$ & $0.81 * * *$ & $0.67 * * *$ & $0.50 * * *$ & $0.64 * * *$ & $0.77 * * *$ \\
\hline Output gap & $0.38 * * *$ & -0.07 & $0.23 * * *$ & -0.12 & $0.33 *$ & -0.08 \\
\hline Public debt (-1) & $0.03 * * *$ & $0.03 * * *$ & $0.06 * * *$ & 0.02 & $0.04 * *$ & 0.01 \\
\hline Structural break? 1/ & no & 1982 & no & no & no & 1990,2000 \\
\hline R-squared & 0.57 & 0.88 & 0.90 & 0.29 & 0.74 & 0.54 \\
\hline Number of obs. & 31 & 32 & 33 & 33 & 32 & 33 \\
\hline \multicolumn{7}{|c|}{ Distinguishing cyclicality in good and in bad times } \\
\hline Constant & $-1.34 * * *$ & $-2.40 * * *$ & $-4.40 * * *$ & -1.09 & $-4.87 *$ & 0.77 \\
\hline Primary balance $(-1)$ & $0.50 * * *$ & $0.86 * * *$ & $0.65 * * *$ & $0.54 * * *$ & $0.58 * * *$ & $0.82 * * *$ \\
\hline Output gap $(+)$ & 0.34 & 0.00 & 0.08 & 0.10 & 1.36 & $-0.43 * *$ \\
\hline Output gap (-) & $0.48 *$ & -0.40 & $0.33 * * *$ & -0.30 & -0.06 & 0.07 \\
\hline Public debt $(-1)$ & $0.02 * *$ & $0.02 * *$ & $0.07 * * *$ & 0.02 & $0.07 * *$ & -0.01 \\
\hline Structural break? 1/ & no & 1982 & no & no & no & 1990,2000 \\
\hline R-squared & 0.57 & 0.87 & 0.90 & 0.21 & 0.58 & 0.49 \\
\hline Number of obs. & 31 & 32 & 33 & 33 & 32 & 33 \\
\hline
\end{tabular}

38. Within each government level, more detailed results support the view that subfederal entities - both the Cantons and the Communes as a whole - are mainly responsible for the destabilizing impact of the general government fiscal stance (Table 4). At the Confederation's level, discretionary policy is broadly neutral to the cycle. This is irrespective of the economy's position in the business cycle, pointing to more effective expenditure control (along with greater attention paid to macroeconomic objectives).

39. The policy response to public debt developments appears to have been weak at all government levels. However, the instability of the estimated relationship is confirmed for the federal level only, supporting the earlier conjecture of a deliberate policy by the Confederation not to revert aggressively the impact of the one-off shocks on its debt. In contrast, the relationship is stable for Cantons and Communes, unambiguously pointing to a systematic lack of intertemporal perspective at these levels. Hence, the combination of subfederal policies appears inconsistent with the stability of their aggregate debt ratio. 
Table 4. Switzerland: Fiscal Behavior by Level of Government (1970-2004) (dependent variable: primary balance in percent of GDP)

\begin{tabular}{|c|c|c|c|}
\hline & Federal & Cantonal & Municipal \\
\hline Constant & -0.29 & 0.17 & 0.06 \\
\hline Primary balance $(-1)$ & $0.61 * * *$ & $0.80 * * *$ & $0.69 * * *$ \\
\hline Output gap $(+)$ & -0.03 & $-0.15 * * *$ & $-0.09 * * *$ \\
\hline Output gap (-) & 0.02 & 0.02 & -0.01 \\
\hline Public debt (-1) & 0.01 & 0.00 & 0.01 \\
\hline Structural break? 1/ & $1991-2000$ & no & no \\
\hline R-squared & 0.38 & 0.63 & 0.70 \\
\hline Number of obs. & 33 & 33 & 33 \\
\hline
\end{tabular}

40. Data availability prevents a more detailed analysis of cantonal macro-fiscal behavior along the lines suggested by equation (1). Systematic analyses of cantonal fiscal performance therefore focus more on explaining the cross-cantonal variance in the size of government (see e.g. Feld and Kirchgässner, 2005) than on assessing their fiscal stance in the light of macroeconomic goals. Still, a number of empirical regularities identified in the literature are worth discussing.

41. First, while tax competition and direct democracy contain the size of cantonal governments, they do not automatically provide them with a fiscal anchor. Institutions that operate symmetrically on primary expenditure and revenues may not effectively constrain deficits and debt accumulation. Also, tying the hands of policymakers may become costly when policy responsiveness to changing circumstances is highly valued. With debt accumulation as the only degree of freedom, it is therefore hardly surprising that cantonal debt levels and debt accumulations are much more diverse than tax burdens (Table 5).

42. Second, both the large number of Cantons and the extent of cantonal disparities make it difficult to internalize national macroeconomic goals, and weaken incentives to enter into binding cooperative arrangements. Intercantonal disparities are considerable on most counts, including size, income, growth, fiscal institutions and indebtedness (Table 5). In that context, it is particularly challenging for subnational policymakers to reconcile local interests with uniform, national objectives, making vertical coordination less easy. Horizontally, coordination is typically harder to sustain when players are numerous and diverse. For instance, predatory tax competition can more easily take place between a small, geographically isolated, rural Canton and a large, urban one, than between two entities of equal size and needs. A key reason is that the large Canton is unlikely to lose out much from its small neighbor's policy. In contrast, two equally sized entities would be more sensitive to the mutually destructive effect of predatory tax cuts, and the mere fear of a race to the bottom (perhaps accompanied with pressures for centralized harmonization) might encourage some degree of coordination. 


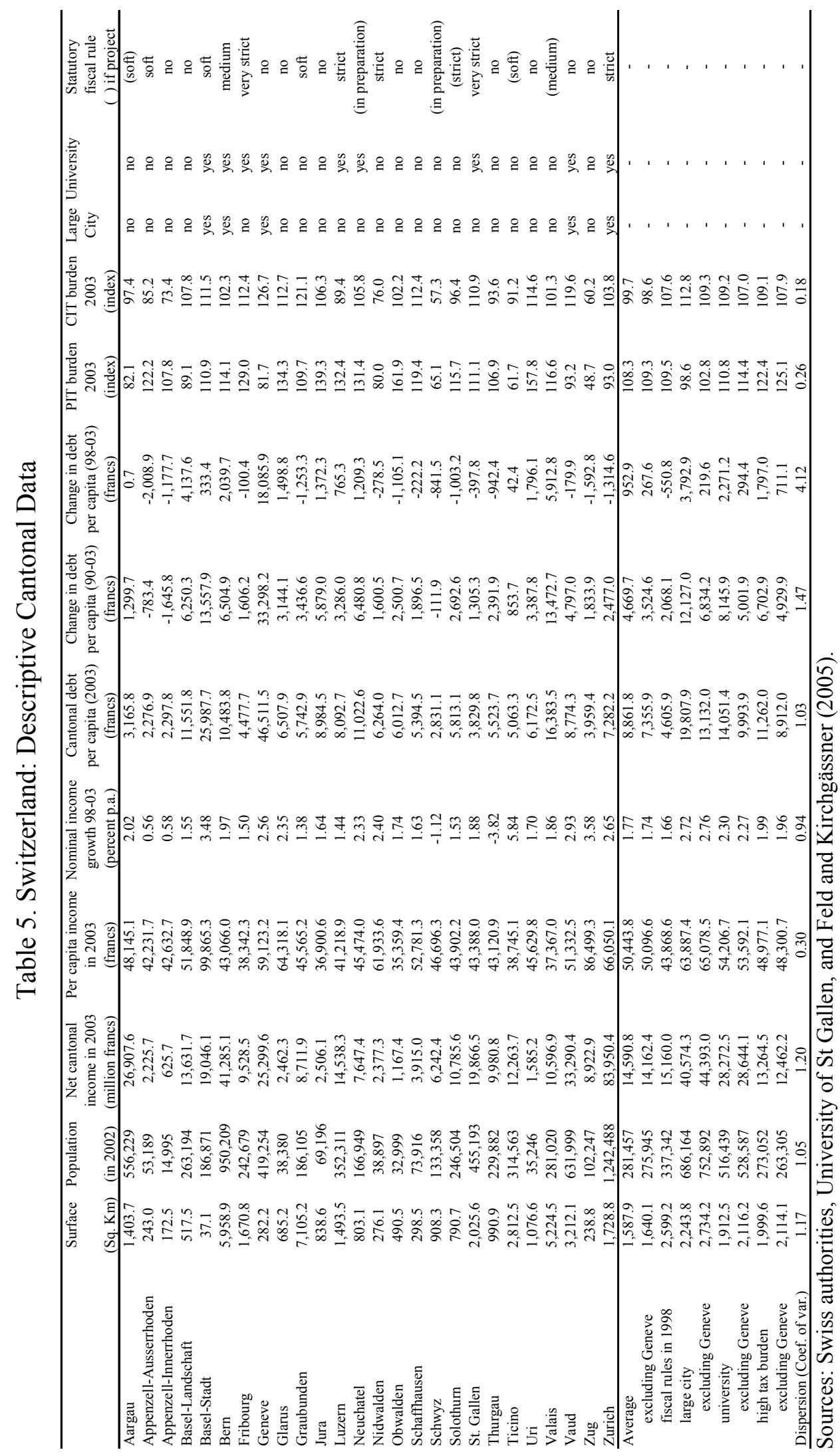


43. Mindful of the potential risk of fiscal indiscipline, a growing number of Cantons have adopted statutory fiscal rules. ${ }^{30}$ Empirical evidence suggests that these rules, based in law, do lead to stronger budget balances on average (Feld and Kirchgässner, 2005). As Table 5 illustrates, both the level of debt and the rate of debt accumulation over the period 19982003 were on average much lower in these Cantons. Currently, 9 cantonal governments operate under statutory "debt brakes" (against 5 in 1998 - see Table 5) while 6 other Cantons have similar projects. However, one specific difficulty in implementing cantonal debt brakes (in comparison to the federal arrangement) is the assessment of cyclical conditions, as there are no data on cantonal output gaps.

\section{Strategic Interactions}

44. Beyond the difficulty to internalize the objectives of other government levels and the existence of institutions tying the hands of policymakers, the extent of coordination problems also depend on the type of interaction among decision makers. This subsection provides some evidence on these interactions in Switzerland.

\section{Horizontally, a chief cause for concern remains a possible increase in tax}

competition. Lower transport and communication costs have increased the mobility of the tax base, and correspondingly, the incentives to use tax policy in a strategic way. Many empirical studies indicate that in competitive federations such as Switzerland, tax policies are set strategically. ${ }^{31}$ Table 6 illustrates this for corporate income taxation (CIT) in selected Cantons of western Switzerland (Dafflon, 2000). In all Cantons but one, CIT payments of a "typical" firm decreased between 1985 and 2003. Early cuts in Bern and Jura between 1985 and 1995 were emulated elsewhere - Geneva excepted - in the second sub-period (19952003). While the cross-cantonal dispersion of CIT payments was broadly constant between 1985 and 1999, it was halved between 1999 and 2003, suggesting a convergence towards lower tax levels.

\footnotetext{
${ }^{30}$ Almost all Cantons have constitutional limits on debt accumulation. In contrast to the US, where constitutional provisions restraining fiscal discretion have direct effects on day-to-day policies (e.g. von Hagen, 1991), statutory provisions appear more effective in Switzerland.

${ }^{31}$ See for instance Hayashi and Boadway (2001) in the case of Canada.
} 
Table 6. Switzerland: Standardized Corporate Income Tax Payments in Selected Cantons

\begin{tabular}{lccccccc}
\hline \multicolumn{3}{c}{} & \multicolumn{5}{c}{ Average rates of change (per annum) } \\
\hline & 1985 & 1995 & 1999 & 2003 & $1985-2003$ & $1985-95$ & $1995-2003$ \\
\hline Bern & 72,028 & 51,710 & 51,681 & 47,329 & -3.2 & -3.3 & -1.1 \\
Fribourg & 61,614 & 59,149 & 58,721 & 55,029 & -0.9 & -0.4 & -0.9 \\
Geneva & 59,641 & 59,607 & 63,342 & 63,567 & 0.5 & 0.0 & 0.8 \\
Jura & 85,582 & 58,723 & 58,549 & 56,416 & -3.2 & -3.7 & -0.5 \\
Neuchatel & 90,180 & 88,897 & 88,565 & 58,240 & -3.3 & -0.1 & -5.1 \\
Valais & 74,704 & 65,325 & 65,204 & 53,638 & -2.5 & -1.3 & -2.4 \\
Vaud & 66,914 & 64,091 & 63,976 & 59,183 & -0.9 & -0.4 & -1.0 \\
\hline Average & 72,952 & 63,929 & 64,291 & 56,200 & -1.9 & -1.3 & -1.6 \\
Dispersion $1 /$ & 0.16 & 0.19 & 0.18 & 0.09 & & & \\
\hline Sourrent Swiss francs)
\end{tabular}

Sources: Dafflon (2000), and Federal Tax Administration.

Notes: Entries in the table are numerical examples of taxes paid on a net profit of 320,000 Swiss francs by a firm with 2,000,000 francs in capital and reserves.

$1 /$ Coefficient of variation across Cantons.

46. Vertically, an important issue is whether interaction patterns between the different layers of government carry risks for macro-fiscal performance. It is already clear from the analysis above that subnational fiscal policies are procyclical. On public debt sustainability, the key issue is whether the pattern of strategic interactions leads to an equitable burden sharing between the Cantons and the Confederation. Specifically, fiscal adjustments and structural fiscal reforms may be harder to achieve if each player engages in beggar-thy-neighbor strategies. For instance, downsizing federal welfare programs - such as unemployment insurance or transfers to asylum seekers - often merely relocates the pressure on social outlays to the cantonal and communal levels. Conversely, the federal level may come under pressure from subcentral entities to cope with structural spending increases in the health sector (IMF, 2004). To assess formally the extent and nature of vertical macrofiscal interactions, simple statistical tests have been performed using aggregate data for Cantons and Communes (Table 7).

\section{Despite the limited size of its budget, the Confederation plays a distinct role in}

the system. Granger causality tests suggest that the Confederation's budget is sensitive to the aggregate fiscal stance of the Communes and the Cantons, whereas only cantonal policies appear (weakly) affected by changes in the federal fiscal stance. As Granger-causality tests are sometimes weak and unreliable, system estimates of equation (1) for each entity have been performed, allowing for the lagged aggregate policy stance of the other two government layers to affect the current policy stance of each entity. Interesting empirical regularities emerge.

- First, the Confederation's budget appears related to subfederal balances in such a way that aggregate slippages (improvements) at these levels are followed by similar developments at the federal level. This is consistent with the idea of the Confederation being a "financier of last resort." 
- Second, the Confederation appears sensitive to subfederal debt developments, and this in a stabilizing fashion consistent with the possibility that it bears the burden of adjustment to the intertemporal budget constraint of the general government. ${ }^{32}$

- Third, the aggregate fiscal stance of Cantonal and Communal governments is largely unaffected by federal fiscal policy, suggesting that pressures on federal accounts are not transmitted to subfederal levels in a systematic way.

Table 7. Switzerland: Indicators of Fiscal Policy Interaction

\begin{tabular}{|c|c|c|c|}
\hline \multicolumn{4}{|c|}{ Granger causality tests: primary balance } \\
\hline & Federal & Cantonal & Municipal \\
\hline Federal does not cause & - & $4.38 * *$ & 2.40 \\
\hline Cantonal does not cause & $9.43 * * *$ & - & 0.37 \\
\hline Municipal does not cause & $4.87 * *$ & 2.18 & - \\
\hline \multicolumn{4}{|c|}{ Granger causality tests: overall balance } \\
\hline Federal does not cause & - & $2.94 *$ & 1.72 \\
\hline Cantonal does not cause & $7.18 * * *$ & - & 0.14 \\
\hline Municipal does not cause & $4.21 * *$ & 1.60 & - \\
\hline \multicolumn{4}{|c|}{ Policy interactions: primary balance response to other levels $1 /$} \\
\hline Primary balance $(-1)$ & $0.51 * * *$ & -0.13 & 0.02 \\
\hline Public debt $(-1)$ & $0.09 * *$ & -0.02 & 0.00 \\
\hline
\end{tabular}

\section{As a result, the Confederation may find it increasingly difficult to maintain fiscal discipline without broader support from other entities. First, transfers to Cantons and to the social security system account entirely for the rise in the Confederation's current primary expenditure (1.3 percent of GDP) over the last 15 years (Figure 7). Second, the limited flexibility of the federal budget on the revenue side implies that the pressure to adjust falls in large part on current primary expenditure net of transfers to Cantons and Social Security. The Confederation's share of "flexible" spending (i.e. goods and services, and capital spending) in total expenditure of the general government declined accordingly, especially after the implementation of the federal "debt brake" rule (right-hand panel of Figure 7).}

\footnotetext{
${ }^{32}$ This result is consistent with the role of one-off debt shocks in the 1990s to explain the apparent lack of responsiveness of the Confederation to federal debt.
} 
Figure 7. Switzerland: Selected Expenditure Indicators for the Confederation

Current primary expenditure (percent of GDP)

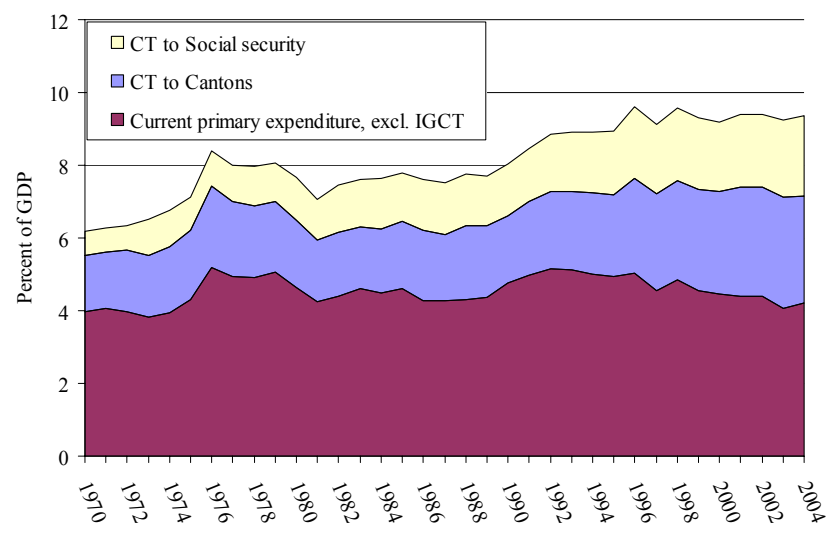

Flexible spending items (in percent of general government expenditure)

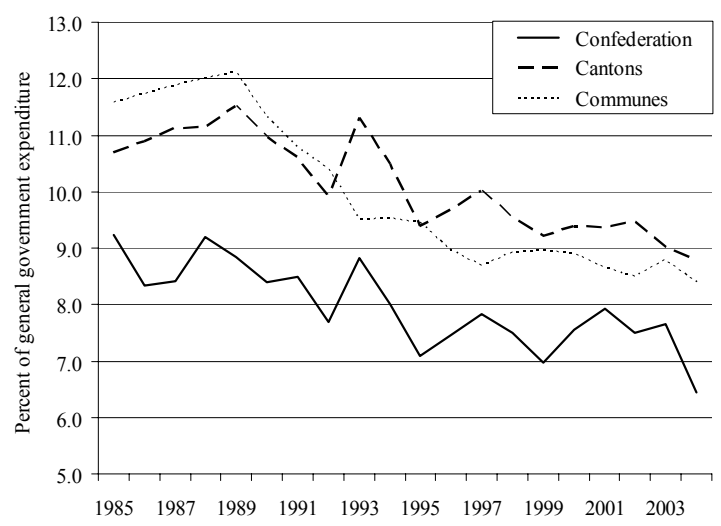

Source: IMF Staff calculations.

\section{Challenges Ahead and Policy Options}

49. The main challenge facing Swiss public finances concerns the long-term impact of population aging. The current system rests on mechanisms - tax competition, direct democracy, and fiscal rules - that tie government outlays to the population's demand for public goods and services. ${ }^{33}$ As discussed earlier, this largely explains the moderate size of the government sector in Switzerland. However, aging-related pressures on existing expenditure programs change the dynamics of the budget at constant policy. Such structural pressures require adjustments for which the system may not be ideally prepared.

\section{Competitive fiscal federalism by itself does not facilitate broad-based support} for a policy package combining structural fiscal reforms and new financing. The likely delays in tackling the aging question would add to the medium term fiscal pressures. Frictions between the Confederation and the Cantons may arise for a variety of reasons, including potential asymmetries in demographics and migration flows, different degrees of fiscal flexibility, an asymmetric distribution of the political costs associated with a given adjustment package, ${ }^{34}$ and last but not least, institutional asymmetries in the distribution of the costs of doing-nothing.

\footnotetext{
${ }^{33}$ While direct democracy contains cantonal expenditure (through fiscal referendums), and strictly caps federal tax rates, tax competition limits the Cantons' room for maneuver on the revenue side. Fiscal rules also provide a fiscal anchor at the federal level and in many Cantons.

${ }^{34}$ This could be the case if the public perceives one specific level of government as having a particular responsibility in social security issues.
} 


\section{By default, the Confederation has been the financier of last resort for Social} Security, and it is effectively exposed to the bulk of spending pressures at unchanged policies. $^{35}$ The social security programs - and especially old-age pensions, disability insurance, and means-tested health-insurance support to households - face no hard budget constraints of their own, relying heavily on transfers from the Confederation. This may encourage free riding on efforts to either provide additional financing to these politically sensitive programs, or to push for their reform.

52. Yet the Confederation is approaching the limits of budgetary flexibility. Federal tax increases are subject to double-majority (i.e., population and Cantons) referenda, margins for expenditure reallocation have narrowed, and the "debt brake" rule formally shuts off the deficit financing option. Cantonal budgets are somewhat more flexible, although the revenue side is constrained by horizontal tax competition, and the expenditure side is often bounded by mandatory referenda on new measures. Moreover, in many Cantons, "debt brake" arrangements formally prevent debt buildups.

53. The overall lack of fiscal flexibility has important policy implications. On the one hand, it forces budgets to remain within strict parameters that are difficult to change unless there is a broad-based support in the population to do so. Strong fiscal commitment should thus tilt the balance in favor of ambitious structural fiscal reforms. On the other hand, reforms tend to have a dynamics of their own driven by their often important distributive effects. The status quo bias in these areas is consequently large, making it difficult to implement any workable reform package in time to prevent the unraveling of the rules-based fiscal framework, and an undesirable drift in public debt.

54. Intergovernmental coordination can reduce these problems. First, increased horizontal coordination in areas such as health and education can bring about significant cost savings. Second, enhanced vertical coordination could reduce the free riding problem associated with the "financier-of-last-resort" role of the Confederation.

55. Informing the public on long-term policy options and trade-offs can help deliver an ex-post coordinated response without the strictures of formal commitments. This takes a special importance in the Swiss context, where strong forms of (ex-ante) vertical coordination are unlikely. Specifically, if voters have information on the policy options and trade-offs facing all government levels, policymakers may find it easier to obtain support in their respective constituencies for policies consistent with a comprehensive reform strategy. In that regard, the periodical publication of a long run fiscal sustainability report that clearly outlines the cost-of-doing-nothing and the policy trade-offs involved can be a useful instrument. Still, better-informed voters are no guarantee against free-riding attempts, especially if the size of the dissenting entity does not threaten the success of the broader strategy.

\footnotetext{
${ }^{35}$ See IMF (2004) and the other papers in this report.
} 
56. Imposing a hard budget constraint on the social security system could also downsize the free riding problem. For example, distinct solvency requirements for social security programs as a whole could reduce the role of the Confederation as the payer of last resort. Admittedly, the implicit commitment not to bail out an entity in charge of politically sensitive expenditures would hardly enjoy immediate credibility. However, this would have the merit to make the magnitude of the looming fiscal problem more evident, and as such, could trigger a broader appetite for reforms, especially if repeated financing crises were to occur.

57. At unchanged structural policies, aging-related pressures are likely to force the Confederation, and to a lesser extent the Cantons, to recover some fiscal flexibility. If the credibility of rules-based fiscal frameworks is to be preserved, then flexibility on the revenue side will have to be augmented proportionately to the lack of flexibility on the expenditure side. For the Confederation, the economically least damaging way to recover tax flexibility would be to allow for temporary adjustments in VAT rates when the debt brake is at risk and room for expenditure cuts is exhausted. Incidentally, such VAT changes would put a clear price tag on eventual delays in implementing structural fiscal reforms. ${ }^{36}$

58. However, greater fiscal flexibility may weaken the strong incentives for cost efficiency present in the Swiss system. To alleviate that problem, permitted VAT increases could be limited in size and over time, and only be allowed as a last resort measure to preserve the debt brake.

\section{E. Conclusions}

59. Significant differences exist in the macro-fiscal behavior of federal and subfederal entities, with severe procyclicality and lack of intertemporal perspective observed in the latter. At the subfederal level, the apparent failure to internalize the solvency constraint underscores the lack of a fiscal anchor. Mindful of the problem, a growing number of Cantons have introduced (or are planning to introduce) statutory fiscal rules.

60. Competitive fiscal federalism arrangements prevailing in Switzerland have contributed to contain the size of the public sector and public debt by discouraging new spending initiatives. However, the system's resilience in the face of pressures from existing entitlement programs is less evident, carrying serious fiscal risks in the context of population aging. In particular, the federal level has so far absorbed the bulk of fiscal adjustment efforts, leaving it with limited flexibility to do more. Yet, under current trends, the center is also likely to bear a large share of aging-related outlays, particularly in the health, disability, and old-age pension sectors. Absent some intergovernmental coordination, the implementation of a credible policy response - a mix of entitlement reform, and revenue increases - could be

\footnotetext{
${ }^{36}$ VAT is not only less distortionary than direct taxes, but it is also relatively low in Switzerland. Moreover, being an exclusive tax of the Confederation, the risk of harmful vertical tax competition is low.
} 
delayed, leaving debt accumulation — and with it, the demise of the fiscal rule — as the only safety valve.

61. The recent reform of financial equalization and of the distribution of tasks between the Confederation and the Cantons provides better incentives for costeffectiveness at the cantonal level, reduces areas of potential friction between federal and subfederal governments, and enhances horizontal coordination among Cantons. However, vertical coordination mechanisms remain weak, possibly slowing down the implementation of solutions to gathering spending pressures.

62. Looking forward, a steadfast implementation of the NFA and enhanced vertical coordination between federal and cantonal levels seem important to improve the ex-post fiscal stance and to guarantee that intertemporal constraints are properly internalized at all government levels. In that perspective, a menu of policy options is available.

63. First, greater transparency with a view to inform the public on longer-term challenges, and on policy options and trade-offs at all levels of the general government could provide stronger incentives for each entity to contribute to a solution (ex-post coordinated response). The long-run fiscal sustainability report currently under preparation is a major instrument to raise public awareness of long-run challenges.

64. Second, consideration could be given to extending "debt brake" arrangements to all decision levels to strengthen the fiscal anchor of the general government, reduce the risk of free riding on adjustment efforts, and spur structural fiscal reforms.

65. Third, to the extent that preserving a credible fiscal anchor is a priority, flexibility in the federal budget, and in particular VAT, may need to be increased. However, such flexibility should be exerted within strict parameters to preserve the strong incentives for cost efficiency present in the Swiss system. 


\section{Appendix}

\section{Data}

The OECD/World Bank (2003) sample covers the following countries:

$\begin{array}{llll}\text { ALGERIA } & \text { ARGENTINA } & \text { AUSTRALIA } & \text { AUSTRIA } \\ \text { BELGIUM } & \text { BOLIVIA } & \text { CAMBODIA } & \text { CANADA } \\ \text { CHILE } & \text { COLOMBIA } & \text { CZECH REPUBLIC } & \text { DENMARK } \\ \text { EGYPT } & \text { FINLAND } & \text { FRANCE } & \text { GERMANY } \\ \text { GREECE } & \text { HUNGARY } & \text { ICELAND } & \text { INDONESIA } \\ \text { IRELAND } & \text { ISRAEL } & \text { ITALY } & \text { JAPAN } \\ \text { JORDAN } & \text { KENYA } & \text { KOREA } & \text { MEXICO } \\ \text { MOROCCO } & \text { NETHERLANDS } & \text { NEW ZEALAND } & \text { NORWAY } \\ \text { PERU } & \text { PORTUGAL } & \text { SLOVAK } & \\ \text { SOUTH } & \text { REPUBLIC } & \text { SLOVENIA } \\ \text { AFRICA } & \text { SPAIN } & \text { SURINAME } & \text { SWEDEN } \\ \text { TURKEY } & & & \\ & \text { UNITED } & \text { UNITED STATES } & \text { URUGAY } \\ & & & \end{array}$


Table A.1. Cantonal "Debt Brake” Arrangements (Active or in Preparation)

\begin{tabular}{|c|c|c|c|c|c|c|c|c|}
\hline & \multirow{2}{*}{ Status } & \multirow{2}{*}{ Main target } & \multirow{2}{*}{ Deficit allowed? } & \multirow{2}{*}{$\begin{array}{l}\text { Target adjusted for } \\
\text { business cycle? }\end{array}$} & \multirow{2}{*}{$\begin{array}{l}\text { Adjustment } \\
\text { strategy }\end{array}$} & \multirow{2}{*}{$\begin{array}{l}\text { Escape } \\
\text { clauses? }\end{array}$} & \multicolumn{2}{|c|}{ Restrictiveness Indices } \\
\hline & & & & & & & IMF staff $1 /$ & ACIR \\
\hline Aargau & Projected & Balanced budget & Yes & $\begin{array}{l}\text { Yes (no correction if } \\
\text { recession, } 10 \text {-year } \\
\text { carry over if } \\
\text { stagnation). }\end{array}$ & $\begin{array}{c}\text { Mainly expenditure } \\
\text { with a 5-year carry } \\
\text { over. }\end{array}$ & Yes & 3 & 5 \\
\hline Appenzell-Ausserrhoden & In effect & Balanced budget & $\begin{array}{l}\text { Yes (cap on deficit of } \\
\text { approved budget) }\end{array}$ & Yes & $\begin{array}{l}\text { Mix with a } 7 \text {-year } \\
\text { carry over }\end{array}$ & Yes & 3 & 3 \\
\hline Basel-Stadt & In effect & $\begin{array}{c}\text { Debt ceiling/ } \\
\text { Expenditure growth }\end{array}$ & Yes & Yes & $\begin{array}{l}\text { Mix with a 1-year } \\
\text { carry over }\end{array}$ & Yes & 2 & - \\
\hline Bern & In effect (2002) & $\begin{array}{l}\text { Stable debt ratio / } \\
\text { balanced budget }\end{array}$ & No & No & $\begin{array}{l}\text { Mix with a 1-year } \\
\text { carry over }\end{array}$ & Yes & 4.5 & 7 \\
\hline Fribourg & In effect (1996) & Balanced budget & No & No & Tax & No & 10 & 9 \\
\hline Graubunden & In effect (1998) & $\begin{array}{l}\text { Balanced budget / } \\
\text { expenditure growth }\end{array}$ & Yes & Yes & $\begin{array}{l}\text { Mix with a 1-year } \\
\text { carry over }\end{array}$ & Yes & 4 & 7 \\
\hline Luzern & In effect (2001) & Balanced budget & $\begin{array}{l}\text { Yes (cap on deficit of } \\
\text { approved budget) }\end{array}$ & Yes & $\begin{array}{l}\text { Mix with a 1-year } \\
\text { carry over }\end{array}$ & No & 6.5 & 3 \\
\hline Neuchatel & In preparation & - & - & - & - & - & - & - \\
\hline Nidwalden & In effect (2001) & Balanced budget & $\begin{array}{l}\text { Yes (cap over a 3-year } \\
\text { horizon) }\end{array}$ & $\begin{array}{l}\text { Yes ("exceptional } \\
\text { circumstances") }\end{array}$ & $\begin{array}{l}\text { Mix with a 1-year } \\
\text { carry over }\end{array}$ & No & 7 & 7 \\
\hline Schwyz & In preparation & - & - & - & - & - & - & - \\
\hline Solothurn & Projected & Balanced budget & Yes (cap) & No & Tax & Yes & 6.5 & 9 \\
\hline St. Gallen & In effect (1929) & Balanced budget & Yes (cap) & No & $\begin{array}{l}\text { Mix with a 1-year } \\
\text { carry over }\end{array}$ & No & 8 & 7 \\
\hline Ticino & Projected & $\begin{array}{c}\text { Expenditure cap } \\
\text { (relative to cantonal } \\
\text { income) }\end{array}$ & Yes & Yes & $\begin{array}{c}\text { Automatic } \\
\text { expenditure cuts }\end{array}$ & Yes & 3 & - \\
\hline Valais & Projected & Balanced budget & No & Yes & $\begin{array}{l}\text { Mix with a 1-year } \\
\text { carry over }\end{array}$ & Yes & 5.5 & 7 \\
\hline Zurich & In effect (2001) & Balanced budget & Yes & $\begin{array}{l}\text { yes (balanced budget } \\
\text { over } 8 \text { years) }\end{array}$ & Mainly expenditure & No & 7 & 5 \\
\hline
\end{tabular}

Source: University of St Gallen, and IMF Staff calculations.

$1 /$ Restrictiveness indices range between 1 (least restrictive) and 10 (most restrictive). When possible, the ACIR index was calculated following the definition provided in Sutherland, Price and Joumard (2005). IMF staff index was elaborated to best capture available information on cantonal rules. A value of 10 corresponds to a strict balanced budget requirement ( 8 for any other main budget target). Points are then subtracted depending on whether (i) deficits are allowed, (ii) targets are adjusted for the business cycle, (iii) carry over are allowed, and (iv) escape clauses exist. The corresponding spreadsheet is available upon request. 


\section{REFERENCES}

Alesina, Alberto, and Allan Drazen, 1991, "Why Are Stabilizations Delayed?," American Economic Review, 81, pp. 1170-88.

Balassone, Fabrizio, and Maura Francese, 2004, "Cyclical Asymmetry in Fiscal Policy, Debt Accumulation, and the Maastricht Treaty", Temi di Discussione No 531, Rome: Banca d'Italia.

Barro, Robert, 1979, "On the Determination of the Public Debt," Journal of Political Economy, 64, pp. 93-110.

Bayoumi, Tamim, and Paul Masson, 1998, "Liability-Creating Versus Non-LiabilityCreating Fiscal Stabilisation Policies: Ricardian Equivalence, Fiscal Stabilisation, and EMU", The Economic Journal, 108, pp. 1026-45.

Beetsma, Roel M.W. J., and A. Lans Bovenberg, 1999, "Does Monetary Unification Lead to Excessive Debt Accumulation?” Journal of Public Economics, 74, pp. 299-325.

Bohn, Henning, 1998, “The Behavior of U.S. Public Debt and Deficits," Quarterly Journal of Economics, 113, pp. 949-63.

Celasun, Oya, Xavier Debrun, and Jonathan Ostry, 2006, "Primary Surplus Behavior and Risks to Fiscal Sustainability in Emerging Market Countries: A "Fan-Chart Approach", IMF Working Paper No 06/67, Washington, D.C: International Monetary Fund.

Dafflon, Bernard, 2000, "Fiscal Federalism in Switzerland: A Survey of Constitutional Issues, Budget Responsibility and Equalization," manuscript, University of Fribourg.

Dafflon, Bernard, 2004, "Le désenchevêtrement des tâches et la péréquation financière: les chantiers de fédéralisme suisse après le 28 novembre," Working paper No 385, Facultés des Sciences Économiques et Sociales, University of Fribourg.

Debrun, Xavier, and Hamid Faruqee, 2004, "Fiscal Behaviors in a Heterogenous Monetary Union: the Case of EMU", manuscript. Shorter version in Chapter II of World Economic Outlook, September 2004, Washington, D.C: International Monetary Fund.

Fatàs, Antonio, 1998, “Does EMU Need a Fiscal Federation?” Economic Policy, 26, pp.165-92.

Feld, Lars, and Gebhard Kirchgässner, 2002, “The Impact of Corporate and Personal Income Taxes on the Location of Firms and on Employment: Some Panel Evidence for the Swiss Cantons," Journal of Public Economics, 87, pp.129-55. 
Feld, Lars, Gebhard Kirchgässner, and Christoph Schaltegger, 2003, "Decentralized Taxation and the Size of Government: Evidence from Swiss States and Local Governments", CESifo Working Paper No 1087, Munich: CESifo.

Feld, Lars, and Gebhard Kirchgässner, 2005, "Sustainable Fiscal Policy in a Federal System: Switzerland as an Example," Working Paper no 2005-16, Basel: CREMA.

Feld, Lars, and Emmanuelle Reulier, 2005, "Strategic Tax Competition in Switzerland: Evidence from a Panel of the Swiss Cantons," CESifo Working Paper No 1516, Munich: CESifo.

Feld, Lars, and Christoph Schaltegger, 2005, "Voters as a Hard Budget Constraint: on the Determination of Intergovernmental Grants”, Working Paper No 2005-21, Basel: CREMA.

Galí, Jordi and Roberto Perotti, 2003, "Fiscal Policy and Monetary Integration in Europe," Economic Policy, 37, pp. 535-572.

Giorno, Claude, and Isabelle Joumard, 2002, "Enhancing the Effectiveness of Public Spending in Switzerland," OECD Economics Department Working papers, No 332, Paris: OECD.

Hayashi, Masayoshi, and Robin Boadway, 2001, “An Empirical Analysis of Intergovernmental Tax Interaction: the Case of Business Income Tax in Canada", Canadian Journal of Economics, 34, pp. 481-503.

International Monetary Fund, 2004, Switzerland-Selected Issues, IMF Country Report No 05/188, Washington, D.C: International Monetary Fund.

Keen, Michael, 1998, "Vertical Tax Externalities in the Theory of Fiscal Federalism", IMF Staff Papers, 45, pp.454-85.

Keen, Michael, and Cristos Kotsogiannis, 2002, "Does Federalism Lead to Excessively High Taxes?”, American Economic Review, 92, pp. 363-370.

Kirchgässner, Gebhard, and Werner Pommerehne, 1996, "Tax harmonization and tax competition in the European Union: Lessons from Switzerland", Journal of Public Economics, 60, pp. 351-71.

Küttel, Dominique, and Peter Kluger, 2001, "Explaining Yield Spreads of Swiss Canton Bonds: An Empirical Investigation," manuscript, University of Basel.

Oates, Wallace, 1972, Fiscal Federalism, New York: Harcourt. 
Persson, Torsten, and Guido Tabellini, 2004, "Constitutional Rules and Fiscal Policy Outcomes," American Economic Review, 94, pp. 25-45.

Schaltegger, Christoph, and René Frey, 2004, "Les restrictions fiscales et budgétaires, un moyen de stabiliser les finances publiques," La Vie Économique, No 2.

Stigler, George, 1957, "The Tenable Range of Functions of Local Governments", in US Congress Joint Economic Committee, Federal Expenditure Policy for Economic Growth and Stability, pp. 213-19.

Sutherland, Douglas, Robert Price, and Isabelle Joumard, 2005, "Fiscal Rules for Subcentral Governments: Design and Impact", Economics Department Working Paper No 465, (Paris: OECD).

Tiebout, Charles, 1956, “A Pure Theory of Local Expenditures,” Journal of Political Economy, 64, pp 416-424.

Van Rompuy, Paul, 2005, "The Coordination of Budgetary Policies in Belgium: 15 years of Experience with the High Council of Finance," manuscript.

von Hagen, Jürgen, 1991, “A Note on the Empirical Effectiveness of Formal Fiscal Restraints," Journal of Public Economics, 44, pp. 199-210.

von Hagen, Jürgen, 1999, “A Fiscal Insurance for the EMU?” in Beetsma, Roel and C. Oudshoorn (eds.), Tools for Regional Stabilization, Discussion Paper No 9903, Dutch Ministry of Economic Affairs.

Wildasin, David, 1991, "Income Redistribution in a Common Labor Market," American Economic Review, 81, pp. 757-774. 


\section{An Indicative Public Sector Balance Sheet for SWitzerland ${ }^{37}$}

\section{A. Introduction}

66. Public sector balance sheets can provide a comprehensive view of the health of the public finances. Traditional fiscal accounts tend to focus on revenues and expenditures (the flow data), but this captures only part of the impact of policies on the public finances. Flow accounts can be usefully complemented by stock indicators. In the 2001 Government Finance Statistics Manual, the Fund is recommending that countries gradually shift to flow and stock accounting. ${ }^{38}$ Since the balance sheet includes financial and non-financial assets, debt, and it could include contingent and forward-looking liabilities, it presents a richer image of fiscal effects and brings out more policy options than flow accounts alone.

\section{Capturing succinctly the impact of future fiscal balances provides additional} information about the fiscal stance and the available policy options and tradeoffs. An intertemporal component in the balance sheet (the "dynamic" forward looking component) can bring out different policy options. Apart from possibly raising taxes or cutting expenditures, policy makers should also investigate options to improve asset management and obtain better investment returns. For instance, in the case of Switzerland, this brings out the importance of using well the proceeds from recent gold sales - either to retire debt or to reinvest these amounts into higher earning alternative assets. In addition, higher returns may be obtained from the public capital stock, by charging user fees or increasing them to cover economic costs. In some cases, the maintenance or construction of public capital stock can be outsourced or privatized. The Swiss authorities are exploring these options, and the balance sheet can help to assess tradeoffs and the impact of reforms that operate over the long run in a succinct way.

68. This paper builds on work done by the Swiss National Bank (SNB, 2005a), which publishes stock data on government financial assets and liabilities. It also reflects the 2005 Article IV Consultation with Switzerland (IMF, 2005a, b, c), which developed a baseline projection of the long-run challenges from aging in the public finances.

69. Moreover, the Ministry of Finance will start using the GFSM 2001 methodology to present a preliminary official public sector balance sheet in 2007. Several cantons will also publish their balance sheets during that year. On a parallel track, in 2007, the Confederation intends to present its long-run sustainability report, with official estimates and projections of the expected fiscal pressures from aging and how these may impact the

\footnotetext{
${ }^{37}$ Prepared by Alina Carare. This paper has benefited from discussions with Messrs. Siegenthaler and Duperrut of the Ministry of Finance, and colleagues in the Swiss staff team.

${ }^{38}$ See for instance the IMF Board paper (www.imf.org) "Using the GFSM 2001 Statistical Framework to Strengthen Fiscal Analysis in the Fund" (p. 14).
} 
different levels of government. This paper cannot be as comprehensive as the authorities' efforts, but it is meant as a precursor to this important work.

70. The structure of the paper is as follows. Section B defines the various components of the balance sheet. Section $\mathrm{C}$ makes a preliminary first attempt to assign separately the main entries to the federal and subnational governments. Section D concludes.

\section{B. Some Preliminary Findings}

71. The SNB has begun to publish financial balance sheet data for the general and central government and the social security system. These show that financial liabilities exceed financial assets - the gap is growing slowly over time. The resulting financial net worth of the combined general government has moved from -23.6 percent of GDP in 1999 to -24.7 percent in 2003 (Table 1). A preliminary staff estimate suggests that the financial net worth was just over -25 percent of GDP by end-2004.

Table 1. General Government Financial Assets and Liabilities

\begin{tabular}{|c|c|c|c|}
\hline & \multicolumn{3}{|c|}{2004 Staff } \\
\hline & 1999 & 2003 & Proj. \\
\hline \multicolumn{4}{|c|}{ (Billions of SwF) } \\
\hline Financial assets & 112 & 142 & 139 \\
\hline Currency and deposits & 20 & 18 & 14 \\
\hline Debt securities & 10 & 8 & 6 \\
\hline Loans & 31 & 27 & 24 \\
\hline Shares and other equity (excl. mutual funds) & 28 & 53 & 58 \\
\hline Mutual fund shares & 0 & 2 & 3 \\
\hline Financial derivatives, other accounts receivable & 22 & 34 & 33 \\
\hline Financial liabilities & -209 & -249 & -251 \\
\hline Currency and deposits & -15 & -6 & -4 \\
\hline Debt securities & -99 & -133 & -143 \\
\hline Loans & -82 & -87 & -85 \\
\hline Shares and other equity (excl. mutual funds) & 0 & 0 & -1 \\
\hline Financial derivatives, other accounts receivable & -13 & -23 & -18 \\
\hline Financial net worth & -97 & -107 & -113 \\
\hline$\%$ GDP & -23.6 & -24.7 & -25.2 \\
\hline
\end{tabular}

Source: Swiss National Bank and IMF staff calculations

72. However, financial net worth is only part of the balance sheet. The net debt may have been used to build public infrastructure to enhance the economy's productive capacity and generate a bigger tax base to service these debts in the future. A complete balance sheet would thus also include the value of the public sector capital stock, as shown below.

73. In addition, future debts from commitments in the social security system, and others, also need to be considered. Estimating the implicit debt involves projecting a long- 
run path for overall fiscal balances. This can be done by constructing a baseline scenario under clearly-defined assumptions - including only the effect of policies already in place. ${ }^{39}$

\section{The 2005 Article IV consultation with Switzerland presented such a baseline} projection (50 years forward looking), including the effects of demographic change over time on potential output and on the fiscal accounts (IMF 2005a, b, c). Some key issues were:

- On current policies, the fiscal deficit would be modest in the short run, but then worsen substantially over time as aging costs play out. ${ }^{40}$

- Several policy options are being considered by the authorities, but these are not yet incorporated in the baseline because they have not yet been approved or implemented. These include the intent to seek public approval for some VAT increase to help finance the disability program.

- In common with other advanced countries, the future deficits in Switzerland are largely emanating from the social security system, which has been running deficits that are projected to grow over time.

75. To incorporate the effects of projected future fiscal balances, such balances were discounted to determine their net present value. We projected overall balances of the general government for a forward looking period of 50 years (2002-2051, 2003-2052, and 2004-2053), using the above described assumptions and an updated macroeconomic scenario. This would result in a gradual deterioration in the public sector net worth (valuation changes were assumed to be zero in the forward looking exercise). The position of the public sector net worth at the end of the 50 year projection horizon then included the full cumulative impact of the baseline policies. This "terminal value" of the net worth was then discounted from its 50 year horizon to the present to see how much in NPV terms the baseline fiscal policies had worsened the net worth relative to its value today. ${ }^{41}$ Adding the NPV of the future fiscal balances to the balance sheet resulted in a net worth that captured the effects of past policies and of those that are projected on a 50-year forward looking basis - together these form the intertemporal balance sheet.

76. The NPV of future fiscal balances suggests a net liability of SwF 681 billion. This estimate is added to the public sector financial balance sheet to construct a preliminary,

\footnotetext{
${ }^{39}$ One could run sensitivity scenario's around this baseline path.

${ }^{40}$ The baseline calculations assume that the debt brake would not be robust to the pressures from aging.

${ }^{41}$ In practical terms, the change in net worth (in NPV terms) was obtained directly by discounting each year's fiscal balance (from the baseline projection) by the terminal value of the discount factor (at year 50). The discount factor each year was calculated using the average annual interest rate on the public debt.
} 
intertemporal financial public sector balance sheet (Table 2). Even though future liabilities have not been formally contracted, they correspond mostly to promises under the welfare state, and thus need to be taken into account. On this basis, the intertemporal financial position is substantially in deficit (SwF 793 billion, or 178 percent of GDP).

Table 2. General Government Expanded Financial Assets and Liabilities

\begin{tabular}{|c|c|c|c|}
\hline & 2002 & \multicolumn{2}{|c|}{2004 Staff } \\
\hline \multicolumn{4}{|c|}{ (Billions of SwF) } \\
\hline Financial assets & 146 & 142 & 139 \\
\hline Financial liabilities & -248 & -249 & -251 \\
\hline Financial net worth & $\overline{-102}$ & $\overline{-107}$ & $\overline{-113}$ \\
\hline NPV of future fiscal balances & -654 & -667 & -681 \\
\hline Intertemporal financial position & -755 & -774 & -793 \\
\hline$\%$ GDP & -175 & -178 & -178 \\
\hline
\end{tabular}

77. To complete the balance sheet, four additional components need to be added:

- Own capital in various publicly managed funds,

- Equity holdings in state enterprises, not yet included,

- The public sector nonfinancial capital stock and,

- Some contingent liabilities from existent government guarantees.

78. Some publicly owned entities have a stock of own capital that has not yet been included. Examples of these are the Polytechnic Schools and the Alcohol Federal Society. According to recent data, their capital amounted to SwF 0.5 billion in 2003-04.

79. Switzerland also has some important enterprise equity holdings that need to be included. Examples are the equity holdings in public sector banks, the SNB, the Post Office, the Federal Railways (SBB), and the confederation's equity participation in Swisscom (SNB 2005 b, 2004, etc.). The confederation, cantons and communes own additional public enterprises, but data on their net worth were not readily available and could not be included.

80. Importantly, the public sector capital stock is a large part of the balance sheet. It comprises the accumulated investments in public infrastructure, government buildings, and machinery and equipment, net of depreciation. In many countries, the public infrastructure is the most important counterpart on the asset side to the gross debt on the liability side. On a preliminary basis, this paper uses estimates by Kamps (2004) which suggest that the Swiss 
net public sector capital stock is equivalent to some 55 percent of GDP (roughly equal to the value of the gross debt in relation to GDP_consistent with an implicit golden rule).

81. Finally, some contingent liabilities are quantified and should be included as well. In this particular case, they comprise central government guarantees to underfunded secondpillar pension funds, valued at SwF 7 billion in 2004.

82. Putting together all components provides a preliminary figure for the comprehensive public sector balance sheet and net worth. Adding in the components just described makes an important difference to net worth. Nevertheless, the Swiss public sector still shows a negative net worth at end-2004 of about SwF 459 billion, or the equivalent of 103 percent of GDP (Table 3, details are in Table 6).

Table 3. Public Sector Balance Sheet

2004

Staff

20022003 Proj.

(Billions of SwF)

A. Intertemporal financial position

B. Other assets

C. Public sector capital stock

D. Contingent liabilities

Net worth $(\mathbf{A}+\mathbf{B}+\mathbf{C}+\mathbf{D})$

$\%$ GDP

$\begin{array}{rrr}-755 & -774 & -793 \\ 93 & 96 & 94 \\ 237 & 242 & 247 \\ -7 & -7 & -7\end{array}$

$\begin{array}{lll}-432 & -443 & -459\end{array}$

$\begin{array}{lll}-100 & -102 & -103\end{array}$

Source: IMF staff calculations (see Table 6 at the end of the chapter).

83. The estimates are preliminary and are sensitive to underlying assumptions, especially those to calculate the intertemporal fiscal position. Data on financial asset holdings tend to be incomplete and may be underestimated. Those on real assets are also likely to be imprecise. Further, the NPV of future implicit liabilities are indicative and depend on key assumptions and developments. Nevertheless, it appears clear that policy adjustments are necessary to counteract the fiscal pressures from aging and to strengthen the comprehensive public sector net worth. The public sector balance sheet may help to understand better the sensitivities of net worth to different assumptions and policiesincluding structural reforms that have an impact on growth and fiscal outturns over the long run (such as a pension reform, which can be costly up-front, but becomes very beneficial over time). Since the public sector balance sheet attempts to capture all effects in an intertemporal way, it can help to communicate to the public why some of these difficult reforms are needed and how they are beneficial. 


\section{The Balance Sheet for the Two Main Levels of Government}

84. The balance sheet so far consolidated the entire public sector. It is also interesting to assign balance sheets to the federal, and cantonal and communal levels, respectively. For financial assets and liabilities, the SNB has published the position at end 2003 for the general government, central government, and social security, respectively. We assumed that the residual, for both financial assets and liabilities, is represented by cantons and communes. The equivalent end-2004 financial assets and liabilities have been estimated for the two main levels of government based on 2003 stocks and respective estimated flows.

85. Future burdens of social programs were assigned as follows. First, it is assumed that the social security system will be running down its reserve assets. Thereafter, the state contributions will be increased, so that in the absence of any social security reform, as deficits materialize, they will be financed by the state. The share of distribution is as follows. It is assumed that the confederation will make transfers to partially cover the costs of health care premia for the poor. In turn, the cantons and communes are assumed to maintain hospitals in their jurisdictions, and contribute the rest to cover the health insurance premia for the poor. The rest of current transfers for old age pensions and disability insurance are assumed to be paid in the same shares by the federal and subfederal governments as is currently the case.

86. Pre-existing assets and liabilities from the detailed balance sheet have been allocated to the confederation and cantons and communes as follows. The special purpose funds, contingent liabilities, and net worth of the SNB were entirely assigned to the confederation. Capital of the cantonal banks was assigned to the cantons. As a working assumption, half of the public sector capital stock has been assigned to the federal government and half to the cantons and communes.

87. As a result, the separate preliminary balance sheets for the confederation and the cantons and communes are in Tables 4 and 5 . The federal government is making efforts to eliminate a small structural deficit, but since it covers the bulk of transfer costs, future social security deficits due to population aging are nevertheless projected to put continued strains on its finances. The cantons and communes also see a weakening in their net worth. About 81 percent of the negative net worth would burden the confederation. ${ }^{42}$

\footnotetext{
42 The net worth of the two main levels of government does not add up exactly to the net worth of the public sector as a whole, because it leaves out some assets held by the social security system independently.
} 
Table 4. Central Government

\begin{tabular}{lrrr}
\hline & & & \\
& & 2004 \\
& & Staff \\
& (Billions of SwF) & 2002 & 2003 Proj. \\
& & & \\
& & & \\
A. Intertemporal financial position & -530 & -538 & -547 \\
B. Other assets & 74 & 74 & 71 \\
C. Public sector capital stock & 119 & 121 & 123 \\
D. Contingent liabilities & -7 & -7 & -7 \\
& & & \\
Net worth (A+B+C+D) & $-\mathbf{3 4 4}$ & $\mathbf{- 3 5 0}$ & $\mathbf{- 3 6 0}$ \\
$\quad$ \% GDP & -80 & -81 & -81 \\
\hline Source: IMF staff calculations. & & &
\end{tabular}

Table 5. Cantons and Communes

\begin{tabular}{|c|c|c|c|}
\hline & 2002 & 2003 & $\begin{array}{l}2004 \\
\text { Staff } \\
\text { Proj. }\end{array}$ \\
\hline \multicolumn{4}{|c|}{ (Billions of SwF) } \\
\hline A. Intertemporal financial position & -248 & -259 & -268 \\
\hline B. Other assets & 19 & 22 & 24 \\
\hline C. Public sector capital stock & 119 & 121 & 123 \\
\hline Net worth $(A+B+C)$ & -110 & -116 & -121 \\
\hline$\%$ GDP & -26 & -27 & -27 \\
\hline
\end{tabular}

Source: IMF staff calculations.

\section{Conclusions and Policy Relevance}

88. A public sector balance sheet can provide a concise intertemporal view of fiscal challenges and can therefore be a useful complement to fiscal flow accounts. Baseline projections suggest that Switzerland faces a substantial financial challenge from aging under current policies. A balance sheet that reflects implicit future debts can help to show that the public finances are less healthy than they may appear based on current deficits or backward looking debt ratios. This can help to stimulate a debate in Switzerland's popular democracy about the important concept of intertemporal fiscal consistency.

89. The public sector balance sheet can be used to analyze the value of fiscal and real structural reforms. Fiscal measures and structural reforms that the authorities are trying to implement should be quantified for their impact on the government's net worth. This way, the public is in a better position to appreciate the value of such policies and may be more likely to support difficult adjustments. 
90. The confederation may be in a good position to show the benefits of a multitude of structural real and fiscal reforms with this new communication instrument. The authorities are preparing an official balance sheet according to GFSM 2001, and a long run fiscal sustainability report, which they aim to publish in 2007. These reports should include the effects of a baseline scenario, but they may also benefit from including reform scenarios that can be used to build public consensus around difficult policy measures. For instance, the rationale behind the frequent recommendations to save the proceeds from the recent gold sales can be shown more easily with the help of a balance sheet than merely employing a budgetary flow presentation. Also, Switzerland has a large stock of important assets, some which could be privatized, or their management could be optimized to increase the returns on these assets. A balance sheet offers valuable insights that can enrich the discussion about fiscal sustainability, especially if it contains forward looking indicators, and is employed alongside the regular budgetary flow accounts. 
Table 6. Detailed Public Sector Balance Sheet

\begin{tabular}{|c|c|c|c|}
\hline & \multicolumn{3}{|c|}{ Staff Projections } \\
\hline & 2002 & 2003 & 2004 \\
\hline \multicolumn{4}{|l|}{ (Billions of SwF) } \\
\hline A. Intertemporal Financial position & -756 & -775 & -793 \\
\hline Financial assets & 146 & 142 & 139 \\
\hline Financial liabilities & -248 & -249 & -251 \\
\hline NPV of future fiscal balances 1 / & -654 & -667 & -681 \\
\hline B. Other assets & 93 & 96 & 94 \\
\hline Special purpose funds $2 /$ & 0.4 & 0.4 & 0.5 \\
\hline Federal Polytechnic Schools & 0.3 & 0.3 & 0.4 \\
\hline Alcohol Federal Society & 0.1 & 0.1 & 0.1 \\
\hline Public sector entities' net worth, as declared in balance sheets & 93 & 96 & 94 \\
\hline Swiss National Bank & 49 & 49 & 45 \\
\hline Swisscom 3/ & 13 & 13 & 13 \\
\hline SBB & 12 & 12 & 12 \\
\hline Post Office & -0.4 & -0.4 & 0.3 \\
\hline Skyguide & 0.1 & 0.1 & 0.1 \\
\hline Ruag & 0.3 & 0.3 & 0.3 \\
\hline Cantonal banks & 19 & 22 & 24 \\
\hline C. Public sector capital stock 4/ & 237 & 242 & 247 \\
\hline D. Contingent liabilities 5/ & -7 & -7 & -7 \\
\hline Net worth $(A+B+C+D)$ & -432 & -443 & -459 \\
\hline \multicolumn{4}{|l|}{ (In percent of GDP) } \\
\hline Financial assets & 33.8 & 32.7 & 31.1 \\
\hline Financial liabilities & -209 & -211 & -209 \\
\hline Intertemporal Financial position & -175 & -178 & -178 \\
\hline Other assets & 21.6 & 22.1 & 21.2 \\
\hline Public sector capital stock & 55.1 & 55.7 & 55.3 \\
\hline Contingent liabilities & -1.6 & -1.6 & -1.6 \\
\hline Net worth & -100 & -102 & -103 \\
\hline \multicolumn{4}{|l|}{ Memorandum items: } \\
\hline Gross debt (SwF billions) & 228 & 234 & 239 \\
\hline in percent of GDP & 53.0 & 53.9 & 53.7 \\
\hline GDP (SwF billions) & 431 & 435 & 446 \\
\hline
\end{tabular}

Source: Swiss National Bank, Federal Finance Administration and IMF staff calculations.

1/ Staff projections of discounted fiscal balances over a period of 50 years. The discount rate reflects the implicit average interest rates on the public debt of each year, compounded to the terminal value discount rate at the end of the 50-year projection period. Projections based on structural and fiscal policies currently in place.

2/ Dedicated funds administered by the Federal Government, not included elsewhere.

3/ Market value of government held shares.

4/ Estimates based on Kamps (2004), IMF Working paper no. 04/67.

$5 /$ Guarantees by the confederation to cover actuarial shortfalls in funded pension schemes. 


\section{REFERENCES}

Da Costa, Mercedes and V. Hugo Juan-Ramon, 2006: "The New Worth Approach to Fiscal Analysis: Dynamics and Rules”, IMF Working Paper/06/17.

Kamps, Christophe, 2004: "New Estimates of Government Net Capital Stocks for 22 OECD Countries 1960-2001” IMF Working Paper No. 67, Washington, D.C.

International Monetary Fund, 2005a: "Intertemporal Policy Consistency in Switzerland: Is the Current Social Insurance Sustainable?", chapter I in "Switzerland: Selected Issues”, IMF Country Report no. 05/188, p. 3-39.

, 2005b: "The Need for Health Care Reform", chapter II in "Switzerland: Selected Issues", IMF Country Report no. 05/188, p. 40-47.

, 2005c: "Switzerland: 2005 Article IV Consultation - Staff Report”, IMF Country Report no. 05/190.

, 2005d: "Using the GFSM Statistical Framework to Strengthen Fiscal Analysis in the Fund", www.imf.org.

, 2006a: "A Preliminary Public Sector Balance Sheet for Germany”, chapter III in

"Germany: Selected Issues", IMF Country Report no. 06/17, p. 35-44.

, 2006b: “Germany: 2005 Article IV Consultation - Staff Report", IMF Country Report no. 06/17.

Swiss National Bank, 2005a: "Swiss Financial Accounts. Stocks of financial assets and liabilities 1999-2003". , 2005b: "Banks in Switzerland". , 2004: “Annual Report”.

Ruag: http://www.ruag.com/ruag/binary?media=118138\&open=true

SBB: 2005 balance sheet: http://212.254.205.12/geschaeftsbericht/pdf/F Bilanz e.pdf

Skyguide:

http://www.skyguide.ch/en/MediaRelations/Publications/downloadables/FACTS FIGURES 05_E.PDF

Swiss medic: http://www.swissmedic.ch/files/pdf/swissmedic_GB_2004.pdf 


\section{A Comparison of The SWISS, DUtCh, AND U.K. Pension Systems, With Emphasis on the OCCupational Pension Pillars ${ }^{43}$}

\section{A. Introduction}

91. Pension systems in many countries have been affected by the challenges posed by aging, persistent low interest rates, and the sharp decline in equity values in 2000-02. Switzerland has implemented some reforms to address these challenges, but additional ones are needed. The public sector pillar of the pension system is generating increasing pressures on the overall government balance. At the same time, the occupational pension pillar has some economic, regulatory, and supervisory risks and weaknesses.

92. To offer a cross-country perspective, this note provides an overview of the Swiss, Dutch and the U.K. pension systems, main issues, and corresponding reforms, with special emphasis on the occupational pension pillar (pillar II). The paper highlights parallels as well as differences among the three systems with the intention to bring out implications and possible options for Switzerland. It picks up on certain features of occupational pension schemes in these countries without intending to describe in full detail all nuances. ${ }^{44}$ In understanding the differences among the three systems, it is useful to make a distinction between the U.K. where pillar I is conceived as a "safety net" and Switzerland and the Netherlands where public pensions are viewed as an important source of retirement income going forward. This has implications for the design of pension reform objectives and the related lessons from cross country experience.

93. One key conclusion of the paper in light of these cross country experiences is that the various administrative constraints imposed on Swiss pension funds may be excessive and limit the efficiency of pillar II. Indeed, there seems to be scope to relax some of the regulatory imperatives that currently limit risk management options of pension funds in Switzerland. The Dutch system, and also the evolving U.K. approach, provide examples of alternative and more market-based systems that are designed to allow institutions manage their risks more freely, with a monitoring system developed by the supervisors with clear and objective triggers for action. In this context, the Dutch system provides an example of a trend towards the introduction of a risk-based funding requirement to the pension system. The $U . K$. in turn adopted long-term funding requirements for occupational pension schemes, and has strengthened the emphasis on transparency and disclosure. Both these approaches offer some "best practices" that are useful for consideration in Switzerland as well.

94. The paper is organized as follows. Sections II, III, and IV discuss the Swiss, Dutch and the U.K. pension systems, respectively, with an emphasis on the regulation and

\footnotetext{
${ }^{43}$ Prepared by May Khamis.

${ }^{44}$ U.K. pension policies are somewhat different from those in Switzerland and the Netherlands. A main emphasis in the U.K. is now how to develop a higher level of private savings against the ongoing gradual scaling down of the public pension system.
} 
supervision of the occupational pension pillar and recent reforms. ${ }^{45}$ Section V concludes with some potential policy implications for Switzerland.

\section{B. The Swiss Pension System}

\section{Overview}

95. The Swiss system is a three-pillar system:

- First pillar. A mandatory pay-as-you-go (PAYG) system administered by the public sector. Employers and employees contribute one-half each of the equivalent of 5 percent of payroll eligible earnings, with no limit to the total contribution. Any shortfall in the PAYG system is funded with general tax revenues. Such transfers from the budget currently cover about 20 percent of old-age and 50 percent of disability pension benefits in this pillar, amounting jointly to 2.7 percent of GDP. Pension benefits are based on average lifetime annual income (upon which contributions have been made) and years of contribution and are subject to a minimum and a maximum per month-SwF 1,075 to SwF 2,150 per month for 2005. This pillar is conceived as a key source of retirement income. Pensions are indexed to wages and prices (with equal weights) after retirement. ${ }^{46}$

- Second pillar. A funded occupational scheme that became mandatory in $1985 .^{47}$ Contribution rates are not specified by law but employers are required to at least match the employees' contributions - in practice, the proportions are about 40/60 of total contribution. Defined contribution (DC) plans cover 77 percent of beneficiaries ( 85 percent of private-sector and 38 percent of public-sector employees) and account for about 85 percent of the total number of occupational plans. Most pension plans are organized as special purpose legal entities, the "foundations", that strictly separate the management of the pension plan from the companies. Employers and employees are equally represented in foundation boards.

- Third pillar. A voluntary personal supplementary system, where employees and selfemployed can take out savings plans tied to retirement.

96. Target pension level. An average combined pension level from the first and second pillars of about 60 percent of final salary.

\footnotetext{
${ }^{45}$ As noted, the discussion is not intended to be exhaustive of all issues or challenges that the three pension systems face. Rather, to set the discussion in the right country-specific context, the paper describes the general aspects and challenges of the three systems.

${ }^{46}$ Adjustments are made every two years with early adjustment in the case of a CPI increase of more than 4 percent.

47 The law requires mandatory coverage for employees age 24 and over and earning annual salary for 2005 between SwF 19,350 and the maximum average pensionable salary for social security purposes of SwF 77,400.
} 
97. Challenges for pillar II. The average funding ratio for pillar II was about 110 percent until 2001, but then dropped well below 100 percent as a result of the sharp decline in equity prices and persistent low interest rates. Although equities have performed well lately, pension funds have not fully recovered yet. In addition, pillar II suffers from regulatory and supervisory weaknesses (below).

\section{Regulation and Supervision}

98. Key issues and elements are:

- Supervision of pension funds is fragmented and uneven among cantons. The registration and, consequently, the supervision of private pensions is widely dispersed across the cantons of Switzerland. In principle, each foundation is registered with the cantonal office where its headquarters are located and where the major part of the business of the employer is conducted. However, for foundations serving employers who carry on business across the country (example is the transport industry pension foundation) or internationally, registration is with the Federal Office of Social Insurance (FOSI). The Federal Office of Private Insurance (FOPI) supervises life-insurance companies, which manage pension funds under collective insurance contracts. Neither FOSI nor the cantonal offices usually perform on-site inspections. The system is a "reliance" model and each foundation is required to file certain key documents at regular intervals with its office of registration. External auditors and certified pension experts of pension funds are legally obliged to report infractions. Neither FOSI nor the cantonal offices currently have the instruments to carry out adequate supervision of pension funds. However, in case of serious problems supervisors can remove the board and appoint an external administrator.

- Funding levels must be maintained at 100 percent plus some cushion to cope with market volatility.

- In case of underfunding:

$>$ funds may request special contributions from fund members or employers;

$>$ funds may reduce the guaranteed rate of return for 5 years; ${ }^{48}$ and

$>$ under very extreme conditions, funds may demand contributions from pensioners (i.e. reduce their net benefits).

- The technical discount rate to calculate the present value of future pension liabilities is not determined by law. However, pension funds currently report their financial positions using a discount rate within a range of 3 to 4 percent (mean 3.9), as recommended by the Chamber of Pension Fund Experts. The continued use of this range despite the decline in interest rates in recent years has the implication that pension fund liabilities are currently underestimated (and therefore overstating the funding level of pension funds). The Chamber has not provided guidelines to lower this range and seems to be divided over

\footnotetext{
${ }^{48}$ The guaranteed rate of return on pension assets is viewed as a consumer protection devise to prevent pension managers from absorbing returns in excessive management fees.
} 
this issue, in part because of uncertainty whether the current low real interest rates are temporary or a permanent feature of the capital markets.

- The conversion rate for private pension funds that translates each individual's invested balance into an annual pension payment from retirement onward, was reduced from 7.2 to 6.8 percent (gradual lowering to 6.8 percent through 2014). In view of the increase of life expectancy and the fall in yields, the Federal Council recommended in January 2006 that the conversion rate be reduced further gradually to 6.4 percent by January 1 , 2011 . $^{49}$ This rate will be reviewed every five years. Given the increase in life expectancy, this rate may still be too high with the implication that a further build up in pension fund reserves may be needed.

- The guaranteed rate of return for mandatory occupational schemes was fixed at 4 percent in 1985, but has been revised down to $3 \frac{1}{2}$ percent in 2002 and $2 \frac{1}{2}$ percent on January 1,2005 . It applies only to the mandatory portion of individual retirement accounts accrued since January 1, 1985. The minimum rate of return is reviewed every two years. Second pillar occupational pension funds are free to choose the extent of price indexation of pensions after retirement, depending on each fund's financial position. This rate, together with the conversion rate, introduce a defined-benefit component into DC occupational pensions.

- Asset allocation restrictions are in place through specific regulatory quantitative limits on investment in various asset classes. These restrictions can be lifted by the pension scheme with justification, and provided that the fund can prove satisfactorily its ability to manage its portfolio prudently. Quantitative restrictions have been relatively eased since 1985. However, remaining restrictions may hamper risk management abilities.

- Foundation boards also put strong emphasis on prudent man rules. ${ }^{50}$ Strategic asset allocation decisions are made by the foundation boards while, typically, a subcommittee of the board, the investment committee, implements the strategy through internal and external fund managers.

- Apart from the above noted conditions, pension funds have substantial flexibility in setting their terms and conditions such as the rate of contribution, and the choice of plan type.

\footnotetext{
49 The new proposed conversion rate is based on an average expected return on assets of 3.85 percent and a discount rate of 3.35 percent. The proposal is pending Parliamentary approval.

${ }^{50}$ That is, assets should be managed prudently to achieve a reasonable investment return, diversify risks and maintain a suitable degree of liquidity.
} 
- Accounting rules: Swiss accounting standards (FER 16). In 2005, Switzerland implemented the IAS $19^{51}$ accounting standard for all internationally active corporations.

- Reporting and disclosure requirements were strengthened in 2004. Reporting and disclosure to fund members were enhanced. An annual funding review of all pension funds by FOSI was introduced based on data provided by the cantonal supervisory authorities. The objective of this review is statistical as FOSI does not have any supervisory authority over pension funds. FOSI submits it final report based on this review to the Federal Council around year-end; i.e. at a 12-month lag after the end of the reporting period. FOSI also introduced a voluntary annual survey conducted directly with pension funds to evaluate the risk capacity of these funds. Annual reports of Swiss pension funds are published.

- Pension benefit guarantees. The Guarantee Fund charges premiums that are proportional to pension funds' size but are not risk-based. ${ }^{52}$ It also subsidizes institutions with an unfavorable age structure.

\section{Recent Reforms}

\section{The Occupational Pension Law (BVG) has been amended in three stages during the period 2004-2006 and a number of reforms were introduced as a result (Box 1):}

\section{Box 1. Switzerland-Amendments to the BVG Law, 2004-06}

Amendments to the BVG Law were made in three stages:

- The first stage, implemented in April 2004, focused on improving transparency and reporting standards.

- The second stage, implemented in January 2005, expanded worker coverage through lowering the earnings threshold for coverage, raised retirement ages for women from 63 to 64 (establishing equivalence with an earlier reform that applied to the first pillar), lowered the annuity conversion rate from 7.2 to 6.8 percent, and mandated certain new benefits similar to those in the first pillar such as widower's pensions and additional categories for disability pension.

- The third stage comprised the Swiss Federal Council passing further revisions to the law to permit greater flexibility in plan design, to reduce the potential for disproportionate employee tax advantages, and to increase the minimum age for early retirement from age 55 to 58 . Beginning January 1, 2006, pension funds will have 5 years to amend their rules and modify operations accordingly.

100. In addition, to address the immediate issue of underfunding, pension funds introduced a series of measures in 2004 (Table 1):

\footnotetext{
${ }^{51}$ Under IAS 19, Companies with DB plans are required to include underfunding of their pension schemes into the Statement of Recognized Claims and Losses. For DC plans where a company's only obligation is to make contributions, the company's contribution is charged as an expense on the income statement, and there is no balance sheet liability.

${ }^{52}$ The fund guarantees statutory benefits owed by insolvent pension funds up to one and a half times the upper limit of the insured salary (i.e. SwF 116,100 for 2005).
} 
Table 1. Corrective Actions by Swiss Pension Funds, 2004

\begin{tabular}{lc}
\hline Corrective action & Number of funds 1/ \\
\hline Reduction in benefits & 36 \\
Higher employer contributions & 13 \\
Higher employee contributions & 10 \\
\hline
\end{tabular}

$1 /$ As percent of total number of funds.

101. Moreover, further reforms were proposed more recently. As noted above, the Federal Council recommended in January 2006 that the conversion rate be reduced gradually to 6.4 percent by January 1, 2011. Additional potential reforms are in the early stages of discussions, such as: (i) the standardization of the regulatory framework for pension funds through the creation of a High Supervisory Board that is financially and legally autonomous and responsible for issuing uniform regulations for the industry; (ii) the full decentralization of pension fund supervision to cantons (or a collection of cantons); (iii) moving away from administratively set technical parameters and asset restrictions; and (iv) a more proactive role for the industry in setting up standards, including quality requirements for auditors.

\section{Particularly, in relation to item (iii) above, a committee of experts made} important recommendations in late 2005 to: (i) abolish the minimum guaranteed rate of return; (ii) abolish the minimum limit on the discount rate and only establish a maximum limit; (iii) make the necessary legal amendments so that the conversion rate can be changed by a decision of the Federal Council instead of the Parliament; and (iii) abolish quantitative restrictions on asset allocation and replace them with adequate asset-liability management. These are important proposals that address the core of the regulatory constraints of pillar II.

103. As regards the supervision of pension funds, the expert committee has proposed a redesign of the supervision framework, with a proposal to give a "High Supervisory Board", possibly within FOSI, the mandate to safeguard the financial stability of pension funds and to harmonize the activities of the cantonal supervisory authorities. This Board would be responsible for issuing general directives to ensure the standardization of regulations throughout the country while the cantons will be fully responsible for pension fund supervision. The proposed system, however, does not seem to address variations in supervisory practices among the cantons. 


\section{The Dutch Pension System}

\section{Overview}

104. The Dutch pension system is also a three-pillar system:

- First pillar. A compulsory PAYG public pension system. Premiums are levied on taxable income at a rate of 17.4 percent with a maximum contribution limit (currently at $€ 5,288)$. People with no income still accrue the benefit entitlement. Shortfalls in the PAYG system are funded with general tax revenues. Benefits guarantee 70 percent of the statutory social minimum wage with no means-testing. ${ }^{53}$ Similar to Switzerland, this pillar is viewed as a key source of retirement income. The retirement age to qualify for this pension is 65 for both men and women. The entitlement builds up by 2 percent for each year of residency between ages 15 and 64, leading to a 100 percent entitlement at age $65 . .^{54}$

- Second pillar. A complementary private occupational pension system. It is noncompulsory, but 92 percent of all workers in the Netherlands participate in it. It is predominantly a defined benefit (DB) system. There is no general statutory obligation for employers to make pension commitments to employees, but data indicate that average employer contributions are around 78 percent of all premiums.

- Third pillar. An individual savings account system managed by private insurance companies. It is primarily used by small businesses (the self-employed) and also by people with gaps in building up an occupational pension.

105. Target pension level. For many years, the authorities aimed for combined benefits from the first and second pillars of 70 percent of the last earned income. A recent reform (see below) lowered this to 60 percent.

106. Challenges for pillar II. The system faced solvency problems in the early 2000 s due to asset valuation losses as a result of the decline in equity prices and persistently low interest rates. ${ }^{55}$ The average funding ratio for the system against nominal liabilities declined from 150 percent in 1999 to a 108 percent in 2002, and around 15 percent of pension funds were below 100 percent. As in Switzerland, the average funding ratio improved after 2002.

\footnotetext{
${ }^{53}$ Seventy percent of the net minimum wage for a single person, 90 percent of the net minimum wage for a single parent with an unmarried child under 18 , and 100 percent of the net minimum wage for a married person or a person living together with a partner (i.e. 50 percent each).

${ }^{54}$ Those living outside the Netherlands for part of this period will receive reduced benefits unless they voluntarily continue participation while living abroad.

${ }^{55}$ Equity investments had increased from 10 percent of total in 1990 to 40 percent in 2000.
} 
As of end-2003, the average funding ratio was estimated to have increased to over 110 percent. $^{56}$

\section{Regulation and Supervision}

\section{Key elements are:}

- Supervision. The Netherlands has recently adopted a cross-sectoral functional approach to supervision. ${ }^{57}$ Within this approach, two supervisory agencies focus on specific supervisory objectives, namely, (i) the soundness of financial institutions and, (ii) the conduct-of-business objective of enhancing orderly and fair market practices.

Accordingly, all prudential supervision was consolidated into a single body within the central bank by merging the supervisory unit of the Netherlands Central Bank (DNB) and the Pension and Insurance Supervisor (PVK). All conduct-of-business supervision was consolidated within the Authority for Financial Markets (AFM). Covenants were established between the two supervisors to ensure good coordination and cooperation.

- Funding levels. See below under recent reforms.

- In case of underfunding, pension Boards (governed by employers and employees) can change the pension terms including benefit provisions subject to a new risk-based supervisory system (see below under recent reforms).

- Discount rate. Consistent with IAS 19. Based on market yields at the balance sheet date on high quality corporate bonds for the same currency and duration of liabilities. If the market for corporate bonds is not liquid, the market yields on government bonds is used with some adjustment to compensate for risk. These guidelines replaced a previous rule that required the use of a discount rate of 4 percent.

- There is no administratively set conversion rate or a minimum guaranteed rate of return.

- Asset allocation. The investment policies of the pension funds are reviewed by the supervisor and funds are required to be "invested in sound manner", but consistent with the risk-based approach, there are no specific prescriptions for asset allocation.

- Accounting rules. Dutch Accounting Standard (DAS) 271 and IAS 19.

- Pension benefit guarantees. There is no guarantee scheme for pension funds.

\footnotetext{
${ }^{56}$ Source: IMF (2004), The Netherlands-Technical Note: Pensions Sector Issues, Financial Sector Assessment Program.

${ }^{57}$ The reforms began in 1999 and are currently in the last stages.
} 


\section{Recent Reforms}

108. To address the solvency issues in the second pillar system and to limit the potential for their reoccurrence, several far-reaching reforms were adopted recently

(Table 2):

Table 2. Corrective Actions by Dutch Pension Funds, 2002-04

\begin{tabular}{lc}
\hline Corrective action & Number of funds 1/ \\
\hline Higher contribution rate & 79 \\
Changes in price indexation 2/ & 67 \\
Move to a career-average basis & 23 \\
Undertake a subordinate loan from sponsor & 16 \\
Reductions in benefits & 10 \\
\hline
\end{tabular}

$1 /$ As percent of total number of funds.

$2 /$ Includes the selection of conditional indexation.

- Contributions were raised. On average, the contribution rate (as a share of wages) has increased from 9.5 percent in 2000 to 16.3 percent in $2004 .{ }^{58}$

- $\quad$ Price indexation of benefits was cut. Pension Fund Boards came to the view that contribution rate increases required to maintain full price indexation may be too high and may unduly harm the labor market. Most pension funds therefore opted for conditional clauses that linked indexation to fund performance. ${ }^{59}$ Furthermore, the basis for benefits was moved from final salary to average salary.

- A new risk-based supervisory framework was introduced. The Principles of the Financial Supervision of Pension Funds, which came into effect in March 2004, required funds to restore coverage of their nominal liabilities to 130 percent within a period of 15 years. A new Pension Act elaborated these Principles and introduced a risk-based supervisory framework, the Financial Assessment Framework (Box 2). The framework introduced new guidelines for assessing the financial position of pension funds including a risk-based funding requirement that takes into account the risks inherent in a pension fund's asset-liability mix. The new framework involves additional reporting and disclosure requirements.

\footnotetext{
${ }^{58}$ Source: IMF (2005), Kingdom of the Netherlands-Netherlands-Selected Issues, IMF Country Report No. $05 / 225$. The rates and the increases vary from one pension fund to another.

${ }^{59}$ Under conditional indexation, pension indexation is dependent on the annual decision of trustees and typically is subject to economic conditions and investment performance of assets. In practice, many pension funds have opted for the conditional form of indexation. The Dutch regulators are strengthening transparency requirements and are requiring companies to make clearer whether they apply a "conditional" or "unconditional" inflationindexation policy.
} 


\section{Box 2. The Netherlands-The New Financial Assessment Framework for Pension Funds}

Effective January 1, 2007, pension funds in the Netherlands will be subject to new tests of funding adequacy and additional reporting and disclosure requirements. Three parallel funding tests will be applied:

- A minimum funding test, requiring pension funds to maintain a minimum of 105 percent funding ratio at all times.

- A continuity test, containing a long-term projection of the solvency position and a "stress" analysis. It shows the results of the minimum funding and solvency tests, performed annually, projected over the next ten years. This test requires funds to describe policy goals and types of policies, and economic assumptions and projections including with respect to short-and long-term interest rates, investment returns, and inflation.

- A solvency test, which introduces an innovative risk-based framework for pension fund management. The risk parameters of pension fund assets would be set so as to guarantee at a 97.5 percent confidence level that the funding ratio will stay above 105 percent over one year (taking into account the expected contribution and expenses during the year). In cases where indexation is not guaranteed, and given certain assumptions, the latter implies a funding ratio, on average, of 130 percent (the current average is 124 percent), to be met within a period agreed on with the supervisor not exceeding 15 years. However, if the ratio falls below 105 percent, it has to be restored within one year, except at times of severe macroeconomic downturns or systemic risk, in which case more latitude would be given. Pension funds can either use their internal models or standard calculations, in a way that resembles the Basel II framework for bank capital adequacy. For most calculations, assets would be marked-to-market, and liabilities would be discounted along the government yield curve with some risk adjustment (depending on their term to maturity). Liability assessments would also include a two year increase in average life spans.

\section{The U.K. Pension System}

\section{Overview}

109. Although it has a number of special characteristics, the U.K. pension system can also be characterized as a three-pillar system:

- First pillar. A two-tier public pension system, which is viewed as a safety net (similar to the U.S., New Zealand, Canada, and Ireland), rather than as an important source of retirement income as in the case of Switzerland and the Netherlands. The first tier is a flat-rate benefit known as the Basic State Pension (BSP), currently $£ 328$ per month to individuals who have worked at least 39 years. ${ }^{60}$ The second is the earnings-related State Second Pension (S2P) to supplement the BSP. Employees with earnings in excess of a Lower Earnings Limit (LEL) will automatically be members in S2P, unless they belong

\footnotetext{
${ }^{60}$ The amount of BSP depends on the number of qualifying years built up before retirement. Those with fewer years of employment receive a smaller benefit. In addition to the BSP, there is a top-up means-tested Pensioner Credit for lower income pensioners.
} 
to an employer's occupational plan or to a personal pension scheme that has been contracted out of S2P. ${ }^{61}$ The self-employed are entitled to the Basic Pension but not to the S2P. State pension age is 65 for men and 60 for women. ${ }^{62}$ The BSP is indexed to the higher of 2.5 percent or retail price inflation after retirement.

- Second pillar. Comprises voluntary occupational pension schemes and are fully indexed to prices after retirement (up to 5 percent per year for most schemes). Employers and employees contribute to this pillar. Over the last 25 years, there has been a decline in the number of active members in private sector occupational pension schemes, accompanied by a major shift from DB to DC schemes. These changes have accelerated in the last 10 years.

- Third pillar. Comprises personal individual or group pension schemes, offered and managed by private pension providers. These schemes provide alternatives for the selfemployed or people with gaps in their occupational pension. Employer-sponsored pensions can also be provided via group personal pension scheme. In these cases, the legal contract is between the individual and the insurance company provider, but with the employer facilitating the process, negotiating the charges, and usually making a contribution. Options include contracted out schemes. ${ }^{63}$

110. Target pension level. No explicit target. The combined income levels of the public and private pension systems for the average pensioner has recently been just around 69 percent of income before retirement (Table 3).

111. Challenges to pillar II. Many DB schemes are winding down as a result of increasing costs of providing pensions because of increasing longevity, lower returns on assets, and lower interest rates. New accounting rules requiring firms to reflect any underfunding of pension funds on the Statement of Recognized Claims and Losses has also meant that volatility of the funding ratio, arising from the mismatch between the risk characteristics of assets and liabilities, could transfer to the company's balance sheet. Since the 1980s, in the face of an aging population, the government started to lower public pension support and cut costs in the first pillar. However, this has led to concern that the levels of

\footnotetext{
61 "Contracting out" means that on retirement, an employee's second pension will come from an occupational or private scheme rather than from the S2P. Schemes can only be contracted out of S2P if they meet certain conditions. The employer and employee pay lower National Insurance Contributions to compensate for the additional State Pension that the employee has given up. In this context, occupational and private pensions can be viewed as a substitute for S2P.

${ }^{62}$ The Thatcher Government raised the state pension age for women to 65 over a ten-year period beginning 2010 .

${ }^{63}$ Contracting out into a personal pension scheme was first allowed in 1978. This resulted in an increase in the number of people covered by private pension schemes and a reduction in the number of people covered by Pillar I's second tier. This trend was reversed from the mid 1990s largely as a result of the "mis-selling" scandal of personal pensions that erupted in December 1993.
} 
savings in the private pension system (Pillars II and III) may not be adequate to offset the reduction in state benefits. ${ }^{64}$

\section{Regulation and Supervision}

\section{Key elements are:}

- Supervision. The Pensions Regulator supervises occupational pension schemes. (The Financial Services Authority regulates life insurance and fund management companies.)

- Funding levels. New regulations (2005) emphasize the long-term solvency of pension funds coupled with a strengthened regime of disclosure and transparency (Box 3). In the new regulations, the Minimum Funding Requirement (MFR) for pension plans was replaced with a long-term, scheme-specific funding standard.

- In case of underfunding the scheme has to provide a "recovery plan" for returning to full funding within ten years, but trustees are encouraged to move faster (i.e. within three to five years). The Pensions Regulator has the power to provide extensions to the time limits, based on each fund's circumstances.

- The discount rate. Market-based. Under Financial Reporting Standard 17 (FSR 17), actuarial liability is calculated using the current rate of return on a high quality corporate bond (rated AA or above) of equivalent currency and duration to the scheme liabilities, or in the absence of such bonds, government bonds plus a margin for assumed credit risk spreads derived from global bond markets.

- No guaranteed rate of return. Pension benefits are indexed to prices (up to 5 percent annually for most schemes). No regulatory conversion rate.

- Accounting rules. FRS 17, which is similar to IAS 19, was issued by the Accounting Standards Board in 2000. Pension funds are required to start its implementation in their 2006 financial statements. Effectively, the new standard has been fully adopted already.

- Reporting and disclosure. Associated with the new funding regulations there is a strong regime of disclosure and transparency. A communication strategy is required to be developed to make certain plan members are informed about the funding of their pension plan. Scheme members and their representatives, unions, and the company's shareholders can scrutinize the scheme's findings and investment plans.

\footnotetext{
${ }^{64}$ A 2004 Pension Commission report estimated that at least 75 percent of all DC scheme members have contribution rates below the level likely to be required to provide adequate pensions. In addition, it is estimated that around 9 million people may be under-saving, some severely.
} 


\section{Box 3. The U.K.-Main Elements of the New Funding Standard for Pension Funds 1/}

Based on the 2001 Myners review of institutional investments, a new funding standard was introduced that replaced the MFR. The main elements of the new standard are:

- The Trustee and Advisors for each scheme are required to publish a scheme-specific funding statement, a Statement of Funding Principles (SFP), which sets out in a clear and straightforward way how it sees its liabilities growing over time and how, through contributions to the fund and growth in the value of assets, it proposes to meet its liabilities. The SFP also sets out assumptions used for projecting its liabilities, including the range of economic scenarios considered. The SFP is intended to complement the Statement of Investment Principles prepared by trustees.

- The SFP should include a "recovery plan" for restoring an underfunded plan to fully funded status. This should be as quickly as the employer can reasonably afford. The Pensions Regulator is likely to intervene if this is longer than 10 years.

- The employer is expected to be fully involved in the discussion about funding and investment plans, and in agreeing to the contribution rates.

- The Pensions Regulator has the authority to establish employer contributions if the employer and trustees cannot reach an agreement on the content of the SFP.

- A schedule of contributions, certified by the actuary, is mandatory.

- Regular actuarial valuations are conducted (required at least once every three years). Trustees determine the actuarial methods and assumptions used, in consultation with the plan actuary.

- Under the new standard, the trustees, actuaries, and auditors have whistle-blowing duties to report to the regulator, particularly in cases where contributions are not being paid according the published funding statement

${ }^{1}$ This Box draws heavily on Blake (2003).

- Pension benefit guarantees. A Pension Protection Fund, introduced in 2004, guarantees DB schemes that are winding up (and all schemes where there have been instances of fraud). The Fund is introducing risk-based premiums and must approve the conditions of takeovers where the acquired firm's scheme is underfunded.

\section{Recent Reforms}

113. The Pensions Commission was appointed in December 2002 with the objective of reviewing the adequacy of private pension saving in the U.K., and advising on potential policy changes, including whether there is a need to move beyond the voluntary approach for earnings-related private pension savings. The Commission published its recommendations in December 2005 and final report in April 2006. The Commission concluded that: 
- The current system of private funded pensions combined with the current state system will deliver increasingly inadequate and unequal pensions; almost half of the working age population over 35 (mostly middle-income earners) is not saving enough to meet likely expectations of retirement income.

- These problems were not soluble through changes to the state system alone, nor by incremental measures to encourage voluntary provision.

- Reforms should instead deal with the major gaps which existed in the current state system and overcome the barriers of inertia and high cost which deter voluntary private pension provision.

114. The main proposals of the Pensions Committee included a restructuring of the public pension system and accelerating the withdrawal from its earnings-related pension provision (i.e. S2P), while a proposed National Pension Savings Scheme for private savings would provide a proven alternative (Box 4). In the long-term the Pension Commission proposals would entail a mixture of increased taxes earmarked for pensions and an increase in state pension ages. However, it is reported that the proposal to abolish means-testing and index state pensions to earnings is seen as too costly by the U.K. Treasury with the expectation that the proposal will involve higher government spending, especially during 2010-2020. The Treasury's view is that this spending would have to compete with other government priorities and should be considered as part of the Comprehensive Spending Review. The Government is expected to release a government white paper on pension reform, responding to the Commission's proposals, in the spring. 


\section{Box 4. The U.K. -Key Proposals of the Pensions Commission}

The main proposals of the Pensions Commission report include:

- A restructuring of the state pension system to make it "as non-means-tested flat rate state pension provision as possible, with the state withdrawing gradually from its role in PAYG earnings-related pension provision (i.e. S2P) as the NPSS (below) provides a proven alternative to earnings-related system". The Committee recommended that, by 2030 , the S2P should be gradually changed from an earnings-related to a flat-rate benefit by freezing the upper-earnings limit for accruals in nominal terms. The Means-Tested Pensioner Credit, which is viewed as a disincentive to personal savings, should be eliminated. The basis for receiving BSP benefits are to be changed from the number of years of active employment to one of residency, to compensate women for work years that are interrupted to raise children and as caregivers. Indexation is proposed to be changed from average growth in prices to average growth in earnings beginning around 2010 .

- Automatic enrollment into a nationally-administered DC pension fund, the NPSS, with the right to optout, and with a compulsory employer contribution. (The NPSS would be financed by an 8 percent contribution rate comprising 4 percent workers' contribution, 3 percent employers' contribution; and 1 percent tax relief or credit.) The self-employed would be allowed to participate on a voluntary basis. This proposal is designed to address the lack of growth of DC or similar long-term savings schemes and the high charges associated with private pensions. Automatic enrollment is thought to increase pension savings because historically such schemes have shown that most people do not opt-out.

- Raising the statutory retirement age, in proportion to the increase in life expectancy to about 67 years by 2050, and to introduce various incentives for people to work longer.

\section{E. "Best Practices" and Implications for Switzerland}

\section{In common with many other countries, the Swiss public pension system is facing} growing financial pressures due to its aging population. The existence of a high level of savings in the private pension system renders these challenges easier to manage in Switzerland compared to several other European countries. Nevertheless, it is important to build upon this achievement, not the least by targeting reforms in the pension system similar to progress made in other sectors in the financial system. The occupational pension pillar in Switzerland faces important challenges primarily regarding fragmented supervision and the predominance of administratively set parameters. Recent reforms implemented in the Netherlands and the UK provide useful examples of new approaches. In particular, pension system reforms in Switzerland should focus on the following areas:

- Strengthening the supervision of pillar II and unifying the system of supervision. A single central office should be given the responsibility of pension supervision throughout the country to ensure the application of uniform supervision. ${ }^{65}$ In addition, there is a need to implement more timely reporting standards. The authorities have made related proposals recently; and an expert committee has suggested a redesign of the structure of pension fund supervision with a "High Supervisory Board" issuing general directives to

${ }^{65}$ A reiteration of the 2001 FSAP mission recommendation, which continues to be valid at this date. 
ensure the standardization of regulations throughout the country while the cantons would remain responsible for supervision. This proposal is a step in the right direction but does not adequately address variations in supervisory practices among the cantons.

- Liberalizing the pension regulatory framework. Under the current system, Swiss pension funds are constrained by regulatory imperatives that weaken the risk management options of pension funds and may limit the long-term resiliency of pillar 2 . Consistent with cross country experience, there is an scope to remove these restrictions, both on the asset side (e.g., direct investment regulations) and on the liability side (e.g., centrally-determined guaranteed rates of return, the technical discount rate, and the conversion rate). Although these parameters are modified periodically, they do not adequately reflect changing market and demographic conditions. In this context, the recent recommendations of the Committee of experts to move away from administratively set technical parameters and restrictions are welcome. Reforms in this area should be complemented by enhanced disclosure and transparency, similar to the U.K. system.

- Consistent with the above recommendations, consideration should be given to reorienting the supervisory framework to a more risk-based system consistent with supervisory changes that are currently being implemented in the banking and insurance sectors under Basel II and the new Swiss Solvency Test (SST). The newly introduced Dutch system provides an example of this approach.

The Swiss FSAP update scheduled for end-2006 can be a good opportunity to explore these and other issues in more detail. 
Table 3. Occupational Pension Systems in Switzerland, The Netherlands, and the U.K.

\begin{tabular}{|c|c|c|c|}
\hline & Switzerland & The Netherlands & The United Kingdom \\
\hline Total assets (as percent of GDP) 1/ & $111.6 \%$ & $106.2 \%$ & $65.1 \%$ \\
\hline Participation rate 2 / & Mandatory 3/ & $92 \%$ & $56 \% 4 /$ \\
\hline Discount rate & Mean 3.9\% & Market-based & Market-based \\
\hline Conversion rate & $6.8 \%$ & $\begin{array}{l}\text { Not prescribed } \\
\text { administratively }\end{array}$ & $\begin{array}{l}\text { Not prescribed } \\
\text { administratively }\end{array}$ \\
\hline Minimum rate of return & $2.5 \%$ & $\begin{array}{l}\text { Indexation to prices. } \\
\text { Could be either } \\
\text { unconditional or } \\
\text { conditional on fund } \\
\text { performance. }\end{array}$ & $\begin{array}{l}\text { Indexation to prices } \\
\text { (up to } 5 \% \text { per year) }\end{array}$ \\
\hline $\begin{array}{l}\text { Overall replacement rate (Public } \\
\text { and private pensions) } 5 /\end{array}$ & $81 \%$ & $78 \%$ & $69 \%$ \\
\hline Benefit system & $\begin{array}{l}\text { Predominantly DC } \\
(77 \%) 6 /\end{array}$ & $\begin{array}{l}\text { Predominantly DB } \\
(95 \%) 6 /\end{array}$ & $\begin{array}{l}\text { Predominantly DB } \\
(84 \%) 6 /\end{array}$ \\
\hline $\begin{array}{l}\text { Supervisory framework } \\
\text { Supervisory Agency }\end{array}$ & $\begin{array}{l}\text { Federal Office for } \\
\text { Social Insurance }\end{array}$ & $\begin{array}{l}\text { The unified supervisory } \\
\text { unit of the Netherlands } \\
\text { Central Bank and the } \\
\text { Pension and Insurance } \\
\text { Supervisor; and } \\
\text { Authority for Financial } \\
\text { Market }\end{array}$ & The Pensions Regulator \\
\hline Minimum coverage ratio & $\begin{array}{l}\text { Funding ratio should } \\
\text { stay above } 100 \\
\text { percent plus some } \\
\text { reserves to cope with } \\
\text { market volatility }\end{array}$ & $\begin{array}{l}\text { Risk based. Funding } \\
\text { ratio should stay above } \\
105 \text { percent over one } \\
\text { year at a } 97.5 \\
\text { confidence interval }\end{array}$ & $\begin{array}{l}\text { Published funding } \\
\text { statements coupled with } \\
\text { a strong regime of } \\
\text { disclosure and } \\
\text { transparency }\end{array}$ \\
\hline
\end{tabular}

1/ Source: OECD, Global Pension Statistics. Data reflect total self-administered pension fund assets as of end-2004.

$2 /$ Number of workers participating in pillar 2 as a percentage of total employees.

3/ The fraction of the labor force not participating in occupational plans include the self-employed, employees with salaries below the mandatory limit, part-time employees and employees with more than one employer.

4/ Source: U.K. Pensions Commission (2004).

5/ Source: IMF, Global Financial Stability Report, September 2004. Pension income, just after retirement, as a percentage of total income just before retirement, for an average two-person household; excludes sources on income other than pension.

6/ As share of total employees. 


\section{REFERENCES}

Blake, David, 2003, The UK Pension System: Key Issues, Pensions, Vol. 8(4), pp. 330-75.

De Gier, Erik, 2003, The Future of the Dutch Pension System: An Essay About threats and Challenges on the Onset of the $21^{\text {st }}$ Century Within the Global Context, International Social Security Association, $4^{\text {th }}$ International Research Conference on Social Security, Antwerp, (May).

Federal Social Insurance Office, Switzerland. Available via the Internet: http://www.bsv.admin.ch/bv/grundlag/e/index.htm

Hewitt Associates, 2005, Legislative Updates. Available via the Internet:

http://was4.hewitt.com/hewitt/resource/legislative updates/europe/europe index.htm\#e urope

Hewitt Associates, 2002, EUFOCUS - Special Edition, (December). Available via the Internet: http://was4.hewitt.com/hewitt/resource/legislative updates/europe/eufocusspecdec02.htm/

International Monetary Fund, 2005, Kingdom of the Netherlands-Netherlands-Staff Report for the 2005 Article IV Consultation, IMF Country Report No. 05/226, (May), (Washington: International Monetary Fund).

,2005, Kingdom of the Netherlands-Netherlands-Selected Issues, IMF Country Report No. 05/225, (June), (Washington: International Monetary Fund).

, 2004, Global Financial Stability Report, (September), (Washington: International Monetary Fund).

,2004, Kingdom of the Netherlands -The Netherlands-Technical Note: Pensions Sector Issues, Financial Sector Assessment Program, (September), (Washington: International Monetary Fund).

Netherlands Bureau for Economic Policy Analysis, 2003, Pension Funds At Risk, CPB Report, (April).

OECD, 2005, Pension Markets in Focus, Newsletter, Issue 2, (December). Available via the Internet: http://www.oecd.org/dataoecd/44/18/35836532.pdf ,2004, Economic Survey-Netherlands 2004: Reforms to Housing and Pension Funds to Increase Economic Efficiency and Reduce Business Cycle Fluctuations. Available via the Internet: http://www.oecd.org/document/50/0,2340,en_2649_201185 31817714_1_1____, 
The Pension Service, United Kingdom, Available via the Internet: http://www.thepensionservice.gov.uk

Queisser, Monika and Dimitri Vittas, 2000, The Swiss Multi-Pillar Pension System: Triumph of Common Sense? World Bank Policy Research Working Paper No. WPS 2416, Vol. 1, (August), (Washington: World Bank).

Social Security Administration, International Update: Recent Developments in Foreign and Public and Private Pensions, (December 2005, August 2005, and October 2004).

Available via the Internet: www.social security.gov/policy.

UBS Global Asset Management, 2004. Available via the Internet: http://www.efundresearch.com/tmp/UBS+Pension+Funds+2004.pdf

U.K. Pensions Commission, 2005, A New Pension Settlement for the Twenty-First Century: The Second Report of the Pensions Commission, (London, U.K.: The stationary Office). Available via the Internet:

http://www.pensionscommission.org.uk/publications/2005/annrep/main-report.pdf

U.K. Pensions Commission, 2004, Pensions: Challenges and Choices: The First Report of the Pensions Commission, (London, U.K.: The stationary Office). Available via the Internet: http://www.pensionscommission.org.uk/publications/2004/annrep/index.asp.

Whitehouse, Edward, 2001, Individual Choice in Social Protection: The case of Swiss Pension, unpublished, (Washington: The World Bank). 